\title{
Edirne Kent Ormanında Zararlı Biyotik Etmenlerin Belirlenmesi
}

\author{
Açelya Çağla BAKKALOĞLU1*, Ömer Kamil ÖRÜCÜ ${ }^{2}$ \\ ORCID 1: 0000-0002-2162-7553 \\ ORCID 2: 0000-0001-7404-6114 \\ ${ }^{1}$ Süleyman Demirel Üniversitesi, Fen Bilimleri Enstitüsü, Peyzaj Mimarlığı Ana Bilim Dalı, 32260, Isparta, Türkiye. \\ 2 Süleyman Demirel Üniversitesi, Mimarlık Fakültesi, Peyzaj Mimarlığı Bölümü, 32260, Isparta, Türkiye. \\ *e-mail: acelyabakkaloglu30@gmail.com
}

Öz

Ülkemizde sanayileşme, hızlı nüfus artışı ve çarpık kentleşmeden kaynaklı sorunların şiddeti artmaktadır. Bu durum doğal ve kültürel değerlere giderek daha fazla zarar vermeye ve habitat alanlarının azalmasına neden olmaktadır. Bu zararı engelleyebilmenin yollarından biri de kent ormanların sayılarını artırarak onlardan sadece rekreasyon anlamında değil ekolojik olarak da faydalanmaktır. Çünkü doğal dengeyi sağlayarak birçok yaşamsal fonksiyonu yerine getirmeyi başarmaktadır Edirne Kent Ormanının farklı alanlarına böcek türlerinin tespiti, populasyon yoğunluklarının ve türlerin ergin uçuş dönemlerinin belirlenmesi amacıyla kent ormanının geneline kırmızı renkli yapışkan Rebell Rosso tuzaklar, delta tipi feromon tuzakları ile üç hunili iskandinav tipi feromon tuzakları tesis edilmiştir. Arazi çalışmalarının yapıldığı dönem boyunca, deneme sahalarında feromon tuzakları ve tuzak ağaçları yardımıyla periyodik kontroller yapılmıştır. Arazide tuzak kontrolleri ergin yakalaması bitinceye kadar sürdürülmüştür.

Çalışma sonucunda 22 tür tespit edilmiştir. Bu türler; Tropinota (Epicometis) hirta (Poda, 1761), Morimus ganglbaueri (Reitter, 1894), Scobicia chevrieri (Villa\&Villa, 1835), Hylurgus ligniperda (Fabricius, 1787), Tomicus minör (Hartig, 1834), Taphrorychus ramicola (Reitter, 1894), Taphrorychus villifrons (Dufour, 1843), Ips sexdentatus (Boerner, 1766), Orthotomicus erosus (Wollaston, 1857), Scolytus mali (Bechstein 1805), S. rugulosus (Müller, 1818), Anisandrus dispar (Fabricius, 1792), Xyleborus monographus (Fabricius, 1792), Trypodendron lineatum (Olivier, 1795), Trypodendron signatum (Fabricius 1787), Xyleborinus saxesenii (Ratzeburg, 1837), Lymantria dispar (Linnaeus, 1758), Malocosoma neustria (Linnaeus, 1758), Thaumetopoea wilkinsoni (Tams, 1926), Archips podana (Scopoli, 1763), A. rosana (Linnaeus, 1758) ve Tortrix viridana (Linnaeus, 1758)'dır. Bu türlerden 14 tanesi Edirne yöresinde ilk kez tespit edilmiştir. Ips sexdentatus (Boerner, 1766), Orthotomicus erosus (Wollaston, 1857)'un Edirne Kent Ormanındaki ağaçlara ciddi zararlar verdiği çalışma sonucunda tespit edilmiştir.

Anahter Kelimeler: Edirne, kent ormanı, biyotik etmenler, zararlı böcek, feromon

\section{Determination of Harmful Biotic Factors in Edirne Urban Forest}

\begin{abstract}
The severity of the problems caused by industrialization, rapid population growth and distorted urbanization is increasing in our country. This situation causes more damage to natural and cultural values and decreases habitat areas. One of the ways to prevent this damage is by increasing the number of urban forests and making use of them ecologically not only in terms of recreation. Because it achieves many vital functions by providing natural balance. In order to determine the insect species in different areas of Edirne City Forest and to
\end{abstract}

Atıf: Örücü, Ö.K., Bakkaloğlu, A.Ç. (2019). Edirne Kent Ormanında Zararlı Biyotik Etmenlerin Belirlenmesi. Mimarlık Bilimleri ve Uygulamaları Dergisi (MBUD), 4 (1), 11-33.

DOI: $\underline{10.30785 / \mathrm{mbud} .509749}$ 
determine the population intensities and adult flight periods of the species, red-colored adhesive Rebell Rosso traps, delta type pheromone traps and three-funded Scandinavian type pheromone traps were established. The ecological balance must be done without any deterioration. For this reason, pheromones, which are usually biotechnical methods, are used. During the field surveys, pheromone traps and trap trees periodic checks were carried out at the test sites. Trap control in the field continued until the adult catch was finished.

As a result of the study, 22 species were identified. These species; Tropinota (Epicometis) hirta (Poda, 1761), Morimus ganglbaueri (Reitter, 1894), Scobicia chevrieri (Villa\&Villa, 1835), Hylurgus ligniperda (Fabricius, 1787), Tomicus minör (Hartig, 1834), Taphrorychus ramicola (Reitter, 1894), Taphrorychus villifrons (Dufour, 1843), Ips sexdentatus (Boerner, 1766), Orthotomicus erosus (Wollaston, 1857), Scolytus mali (Bechstein 1805), S. rugulosus (Müller, 1818), Anisandrus dispar (Fabricius, 1792), Xyleborus monographus (Fabricius, 1792), Trypodendron lineatum (Olivier, 1795), Trypodendron signatum (Fabricius 1787), Xyleborinus saxesenii (Ratzeburg, 1837), Lymantria dispar (Linnaeus, 1758), Malocosoma neustria (Linnaeus, 1758), Thaumetopoea wilkinsoni (Tams, 1926), Archips podana (Scopoli, 1763), A. rosana (Linnaeus, 1758) and Tortrix viridana (Linnaeus, 1758). 14 of these species were first record for. Edirne region. Ips sexdentatus (Boerner, 1766), Orthotomicus erosus (Wollaston, 1857) was found to cause serious damage. Against harmful insects in Edirne City Forest; mechanical controlling, biological controlling, biotechnical controlling and integrated controlling methods should be used.

Keywords: Edirne, urban forest, biotic factors, pest insect, pheromone.

\section{Giriş}

Sanayileşmenin artmasıyla birlikte sınırlı olan doğal kaynaklarımızın değeri ve sürdürülebilirliği daha da önemli hale gelmiştir. (Çüçen, 2007). Çünkü kentsel yeşil alanlar kaliteli yaşam, sağlık ve ölüm oranı gibi insanları direk etkileyen önemli unsurlarından birini temsil etmektedir. Bu yüzden doğal kaynakların değerlendirilmesi ve bu sorunların üstesinden gelmek sosyal bir ihtiyaç haline gelmiştir. Rekreasyonel taleplerin artması yeşil alanlara olan yönelimi artırmıştır. Bu ihtiyaçn giderilmesinde yardımcı olan kent ormanları önemli bir rol oynamaktadır. Kent ormanları, kentsel çevrenin önemli ve giderek daha da değerlenen bir bileşenidir (Dwyer vd., 1992). Kentler için en önemli rekreasyon alanı öğelerinden biridir. Özellikle nüfusun \%70'e yakınının kentlerde yaşadığı ülkemizde kent içinde ve çevresindeki orman gibi yeşil alanlar yoğun insan baskısı altına girmiştir. Yeşil alan varlığımızın (kent ormanları, parklar, vb.) bilinçsizce kullanımı da sürdürülebilirliğinin negatif yönde etkilenmesine, insanların ruh ve beden sağlığı üzerinde olumsuz etkiler yaratmasına neden olmuştur (Uslu ve Ayaşlıgil, 2007; Sağlam, 2012).

Ekosistemde canlıları etkileyen faktörler abiyotik (cansız) ve biyotik (canlı) faktörler olarak iki grupta değerlendirilir. Abiyotik (cansız) faktörler, belirli bir çevrede hangi türlerin yaşayabileceğini belirleyen canlıların yaşamlarını devam ettirebilecekleri çevresel koşullardır. Abiyotik zararlılar iklim ve toprak faktörlerinin verdiği zararlardır (Bilgili, 2011). Güneş ışığı, pH, iklim, su, sıcaklık, toprak ve mineraller gibi tabiattaki canlı varlıkların hepsine biyotik (canlı) faktör denir. Biyotik faktörler arasındaki olumlu ilişki çok önemlidir. Çünkü ekosistemde canlılığın devamı buna bağlıdır (Anonim, 2014a). Biyotik zararlılar; Insanlar, hayvanlar ve bitkiler olmak üzere üç' e ayrılır (Bilgili, 2011). Biyotik zararlılar bitkilerin çeşitli kısımlarında olup onların gelişimlerini zorlaştırır. Bitkiler bu zararlılara karşı savunma yaptıkları halde genellikle yenilir ve daha zorlu durumlarda da tamamen kuruyarak ölürler. Bu zararlılara biyotik zararlıların bitkilerde meydana getirdikleri semptomları yakından izleyerek zararlıların türünü tespit ve teşhis etmek, koruma tedbirlerini almak, bunun da yeterli olmadığı hallerde zararlı ile mücadeleye geçilmesi gereklidir. Biyotik zararlılar; İnsanlar, hayvanlar ve bitkiler olmak üzere üç' e ayrılır (Çanakçıoğlu, 1985).

Bir diğer zarar veren faktör ormanlarımızın sürdürülebilirliğini tehlikeye sokan önemli tehditler arasındaki orman zararlısı böceklerdir (Yıldırım, 2011). Böceklerin populasyon yoğunluklarının saptanmasında, biyolojilerinin incelenmesinde, ergin uçuş periyotlarının belirlenmesinde ve göçlerinin izlenmesinde tuzaklardan yararlanılır.

Bunun için yapılan çalışmada Edirne bölgesindeki böcek türlerini tespit etmek için 3 çeşit tuzak kullanılmıştır. Bunlar İskandinav tipi üç hunili tuzak, delta tuzak ve kırmızı kanatlı yapışkan tuzaktır. Insanlarla böcekler arasındaki ilişki sonucu böcekler yararlı ve zararlı olarak sınıflandırılmış, zararlı böceklerle savaşırken yararlı böceklerin çoğaltılması için yoğun çalışmalar yapılmıştır 
(Arslangündoğdu, 1999). Diğer etmenlere göre böcek zararları çok daha önemli bir yer tutmaktadır (Can, 2005; Sarıkaya, 2008; Yıldırım, 2011). Kabuk böcekleri ormanlarımızda zarara neden olan böcek grupları içinde en önemlilerinden birisidir (Yıldız, 2012; İbiş, 2015). Böceklerin verdikleri zarar bitkilerin kurumasına hatta yok olmasına bile neden olduğu görülmüştür (Sönmezyıldız, 2006). Bu çalışmanın amacı, Edirne Kent Ormanında zarara neden olan biyotik kaynaklı etmenleri tespit edilmesidir. Edirne ili kent ormanında zararlı böcek türleri başta olmak üzere etkili olan biyotik etmenler ilk kez bu çalışmayla detaylı olarak ortaya konulmuştur.

\section{Materyal ve Yöntem}

Meriç havzasında yer alan il toprakları, $40^{\circ} 30^{\prime}$ ve $42^{\circ} 00^{\prime}$ kuzey enlemleri ile $26^{\circ} 00^{\prime}$ ve $27^{\circ} 00^{\prime}$ doğu boylamları arasında kalmaktadır (Şekil 2.1). Trakya'da İstanbul'dan sonra ikinci büyük ilidir. Edirne Kent Ormanı kentin yeşil alan sistemini oluşturan önemli bir öğedir. Orman alanının büyüklüğü $672.501 \mathrm{~m}^{2}$ dir. Kent Ormanı şehir merkezine $2 \mathrm{~km}$ uzaklıkta yer alan Edirne-Karaağaç karayolu üzerinde ve Meriç Irmağı kıyısında bulunmaktadır (Anonim, 2014b).

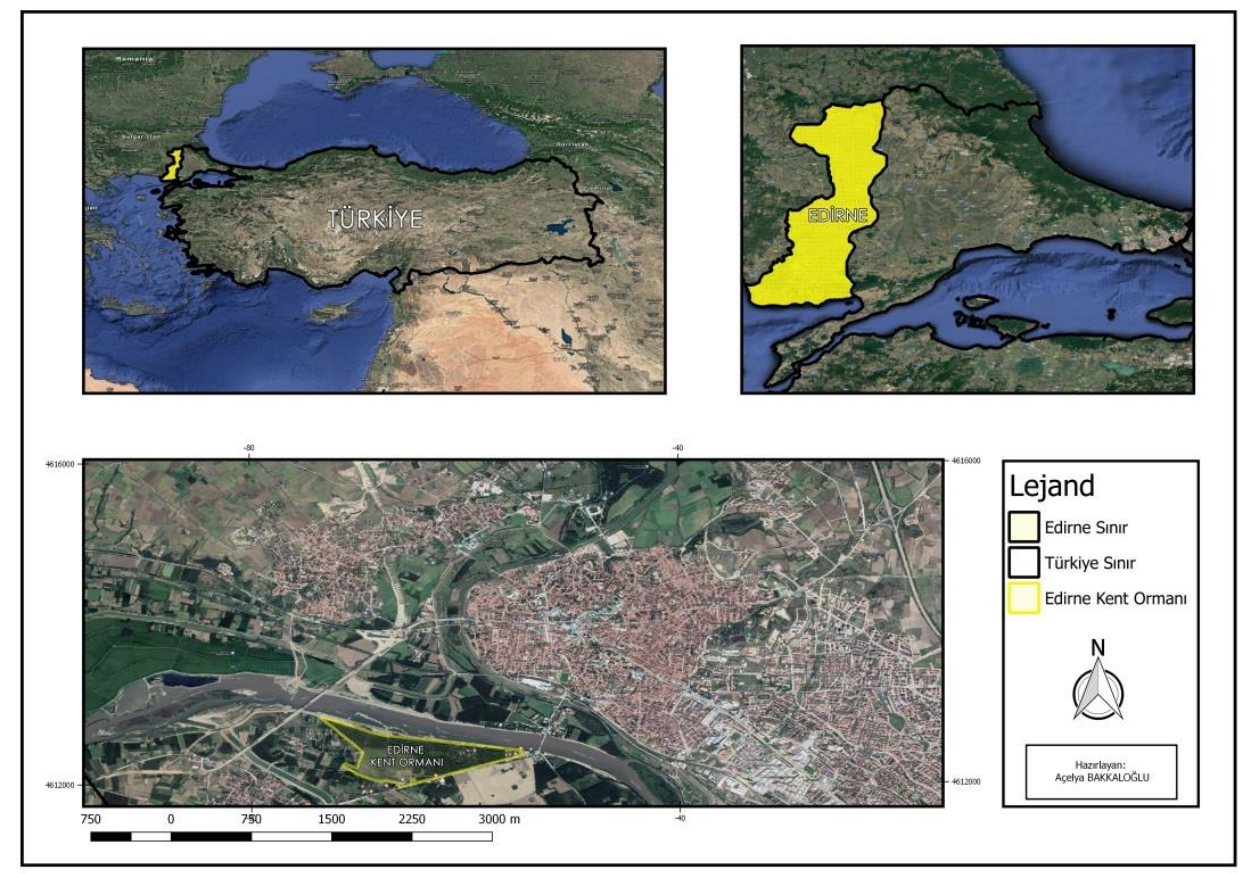

Şekil 2.1. Edirne Kent Ormanı Konumu

Araştırmanın yöntem kısmı iki başlık altında ele alınmıştır. Araştırmanın ilk bölümünün yöntemini çalışma hazırık, literatür taraması, veri toplama, analiz ve sentez programları olmak üzere dört aşamadan oluşmaktadır. íkincisi ise arazi faaliyetleri, gözlem, bulguların toplanması ve toplanan verilerin teşhisi olmak üzere dört aşamadan oluşmaktadır.

\subsection{Edirne Kent Ormanındaki Biyotik Zararlılar}

İnsan kaynaklı zararlar: Ormanlık alanlar için en büyük tehlikeyi böceklerin meydana getirmektedir. Ancak bu alanlara ikinci en büyük zarar insanlar tarafından verilmektedir. Çünkü gelişmekte olan ülkelerde kentleşme, nüfus artışı, tarım alanlarının yetersizliği ve sanayileşme ormanlık alanların gittikçe azalmasına neden olmaktadır (Çanakçıoğlu, 1985; Bilgili, 2011). Edirne Kent Ormanında insan kaynaklı verilen zararlarda vandalizmin etkisi görülmektedir Kentsel yeşil alan kapsamında oluşturulan mekânlardan olan kent ormanlarının denetlenebilir bir yapıya sahip olmaması, görsel kontrolünün düşük olmasından dolayı bu mekânlarda vandalist eylemler meydana gelmektedir. Vandalizm çevreyi olumsuz yönde etkileyen bir eylemdir. Ayrıca, görsel kirliliğe de neden olmaktadır (Olgun, 2013). Kent ormanlarında meydana gelen vandalizm eylemleri, kent ormanı içerisindeki parklarda bulunan donatı elemanlarının fonksiyonel ve estetik kayıplara uğramasına yol açar.

Bitkisel zararlı: Edirne Kent Ormanında görülen bitkisel zararlı ökse otudur. Zarar verme şekli yapraklı ve iğne yapraklı ağaçların öz suyunu emerek ağacı zayıf düşürür ve sonucunda çeşitli kabuk 
böceklerinin gelmesine zemin oluşturur Ayrıca Kökleri ile bitkinin besin maddesini alır ve normal gelişimini önler hatta bazen de bitkiyi kurutarak öldürür. Ökse otu (Viscum album) sürekli yeşildir. Beyaz veya sarımsı meyveleri vardır. Tohumları ilkbaharda çimlenir. Yapışkan bir madde salgılar. Kök ucu bitkiye yapışır. Ökse otları kesilerek çıkartııır yani mekanik mücadele yapılır (Çanakçıoğlu, 1985; Bilgili, 2011)

Hayvansal zararlılar: Edirne Kent Ormanında zarar yapan hayvanlar; karga, ağaçkakan, sincap, fare, tavşan ve köstebektir. Genellikle tohumları yiyerek zarar yaparlar. Fakat bu hayvanların birçok yararı da bulunmaktadır ama aradaki yarar-zarar dengesi popülasyonlarının yoğunluğuna göre değişiklik göstermektedir.

\subsection{Edirne Kent Ormanında Zararlı Böcek Türlerinin Tespit Edilmesi}

Tez çalışmaları, Edirne Kent Ormanı genelinde gerçekleştirilmiştir. Arazi çalışmaları böcek türlerinin uçma zamanları göz önünde bulundurularak, 2018 yılında, yıl içerisinde mart ayı başlarından itibaren kasım ayı sonuna kadar olan periyodu içerisine alan süreçte yürütülmüştür. Arazide böcekleri elde etmek amacıyla, bağlı olduğu takıma, bitki üzerinde yaptığı zararın şekline ve aktif oldukları zamana göre ağaç dallarının silkilmesi, feromon tuzakları, görsel tuzaklar ve funnel tipi tuzaklar gibi çeşitli yöntemlerden faydalanılmıştır.

Zararlı kelebek türlerinin tespiti ve ergin uçuş periyotlarının belirlenmesi amacıyla araştırma alanını ağaç türlerine göre temsil edebilecek konumda bulunan ağaçlara böceklerin uçma zamanından önce Delta tipi feromon tuzakları tesis edilmiş ve tuzaklarda türe has feromon preparatları kullanılmıştır (Şekil 2.2). Bu amaçla, Lymantria dispar, Thaumetopoea wilkinsoni, Archips podana ve Tortrix viridana türlerine ait türe has feromon preparatları Delta tipi tuzaklarda kullanılmıştır.

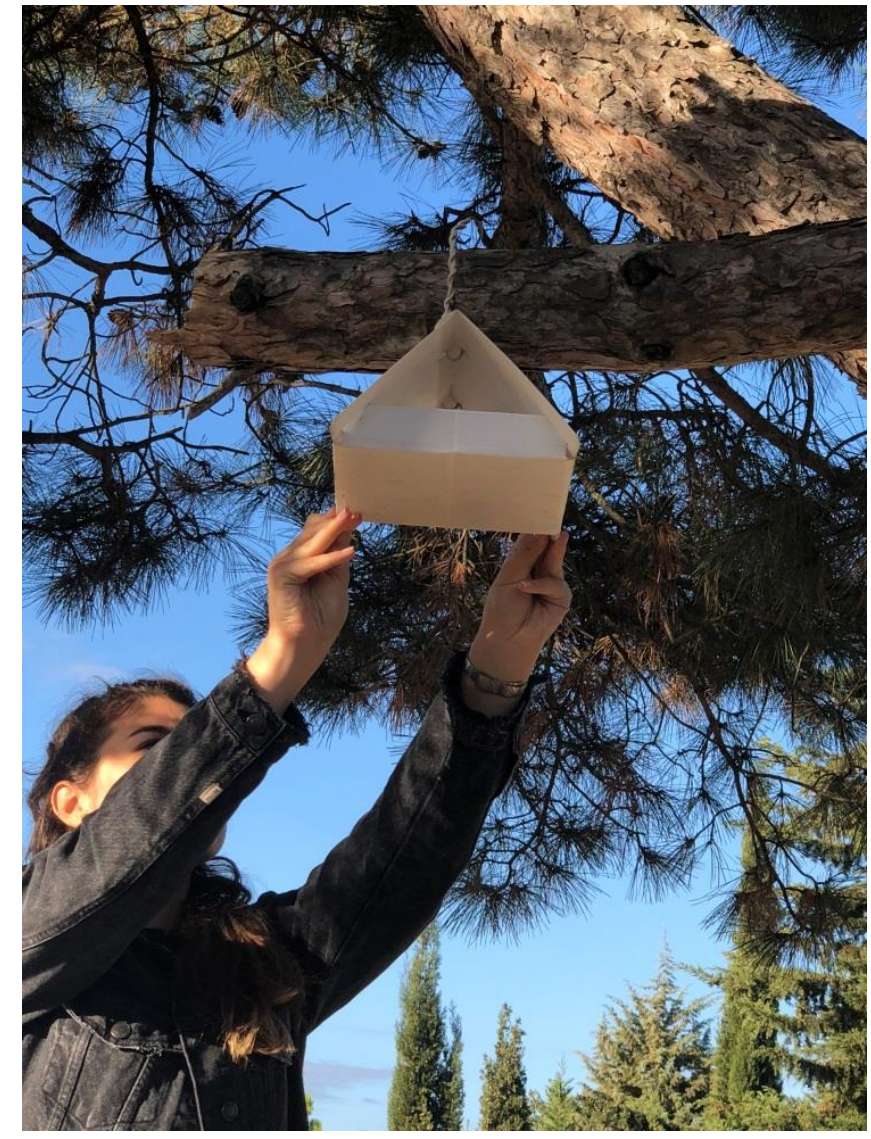

Şekil 2.2. Delta tipi feromon tuzağı

Araştırma sahasına, türlerin aktif uçma periyotlarının olduğu dönmelerde 10 gün aralıklarla gidilerek feromon prepatları ve tuzakların yapışkan tablaları kontrol edilmiş ve yenisi ile değiştirilmiştir. Tuzaklardaki erginler sayılarak kayıt altına alınmıştır (Şekil 2.3). 


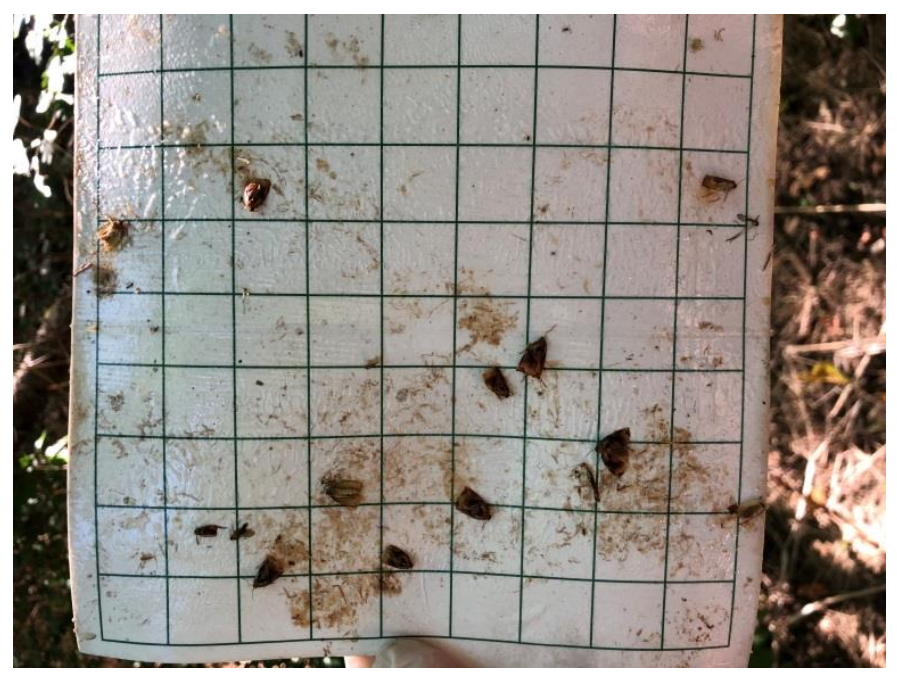

Şekil 2.3. Kontrollerde elde edilen, yapışkan tablaya yapışmış olan erginler

Kabuk ve kambiyum zararlısı türleri tespit etmek için böceklerin uçma zamanından önce çalışma alanlarına türe has feromon preparatlarının kullanıldığı "iskandinav tipi üç hunili" feromon tuzakları (Şekil 2.4) asılmış, bazı türlerin tespiti için ise saha geneline Kırmızı renkli yapışkan Rebell Rosso tuzaklar (Şekil 2.5) (\%96'ık etil alkol ve \% 1 toluenden oluşan cezbedici karışım ile) tesis edilmiştir. Tuzaklar periyodik olarak kontrol edilerek, sayımları gerçekleştirilmiştir. Bunun yanı sıra böcek zararından dolayı zayıf düşmüş, kurumakta olan dikili ağaçlardan ve kesilmiş, devrik ağaçlardan da örnekler alınmıştır. İskanidnav tipi feromon tuzaklarında Ips sexdentatus ve Orthotomicus erosus'a has feromon preparatları kullanılmıştır. Bu türlerin haftalık kontrollerinde feromon tuzaklarının böcek toplama haznesinde biriken tüm böcekler dal, iğne yaprak v.b. materyalden arındırıldıktan sonra plastik böcek taşıma kavanozlarına alınarak laboratuvara getirilmiştir. İskandinav tipi üç hunili feromon tuzakları $80 \mathrm{~m}$ aralıklarla ve her bir deneme sahasına 5'er adet olacak şekilde, Rebell Rosso kırmızı kanatlı yapışkan tuzaklar ise ağaçların dallarına, birbirine en az 80-100 m aralıklarla yerden 22,5 m yüksekliğe asılmıştır.

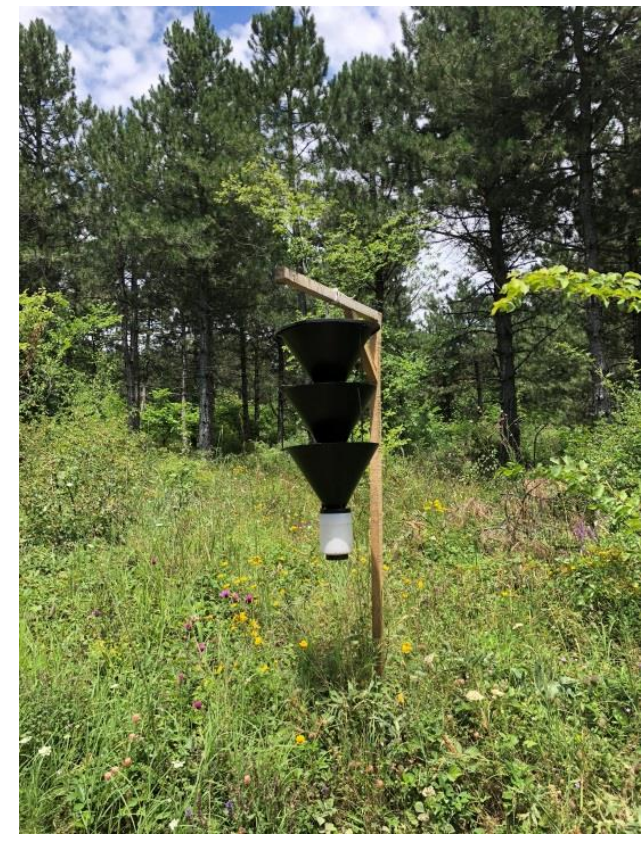

Şekil 2.4. İskandinav tipi üç hunili feromon tuzağı 


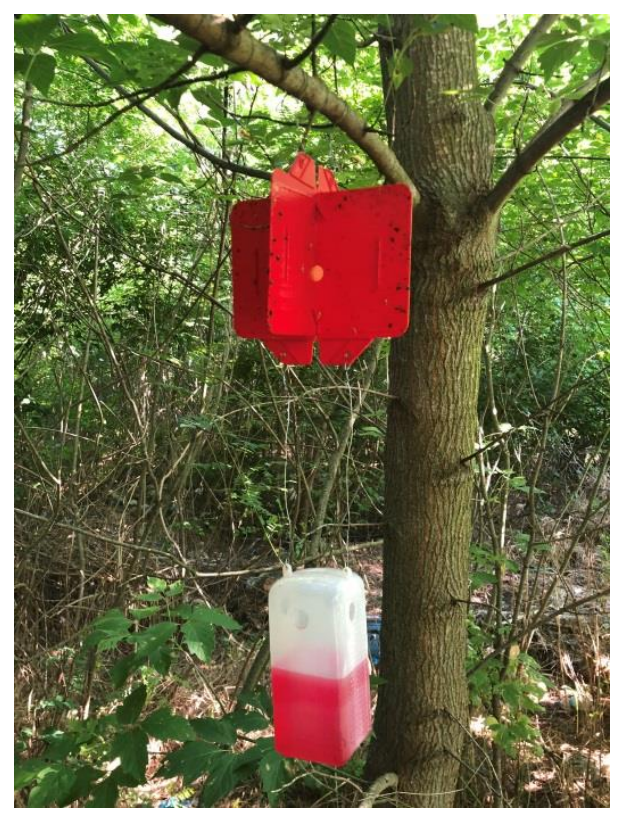

Şekil 2.5. Rebell Rosso kırmızı kanatlı yapışkan tuzaklarda böcek kontrolü

Kontroller, İskandinav tipi üç hunili feromon tuzaklarında haftada bir, Rebell Rosso kırmızı kanatlı yapışkan tuzaklarda ise ayda bir kez olacak şekilde gerçekleştirilmiş, arazide tuzak kontrolleri ergin yakalaması bitinceye kadar devam edilmiştir.

Araziden toplanan böcekler stereoskopik mikroskop altında incelenerek tür ayrımları gerçekleştirilmiştir. Türlerin teşhisi, Doç.Dr. Oğuzhan SARIKAYA (Isparta Uygulamalı Bilimler Üniversitesi Orman Fakültesi), Doç. Dr. İsmail ŞEN (Isparta Uygulamalı Bilimler Üniversitesi Teknoloji Fakültesi) ve Dr. Michail MANDELSHTAM (St. Petersburg Müzesi-Rusya) ve Dr. Milos KNižEK (Prag Ormancılık ve Yaban Hayatı Araştırma Enstitüsü-Çek Cumhuriyeti) tarafından gerçekleştirilmiştir.

\section{Bulgular ve Tartışma}

Edirne Orman İşletme Müdürlüğü sahalarında yayılış gösteren 22 adet tür tespit edilmiştir. Aşağıda verilen bu türlerin, Takım, Familya, Alt Familya, Tribus, Cins ve Türlerinin sıralanmasında Faunaeur (2018) ve Knížek (2011)'den faydalanılmıştır.

\subsection{Türlerin Tanımı ve Arazi Gözlemleri}

\subsubsection{Tropinota (Epicometis) hirta (Poda, 1761)}

Tropinota hirta (Şekil 3.1) erginleri Türkiye'de gül bahçelerinde, vişne, böğürtlen, ahududu, kayısı, şeftali, nektarin ve süs bitkilerinde zararlı olmaktadır. Zarar verdiği tespit edilmiştir. (Kaya ve Kovancı, 2004; Öztürk vd., 2004; Özkan vd., 2005; Çetin vd., 2006; Demirözer, 2008; Hazır, 2008).

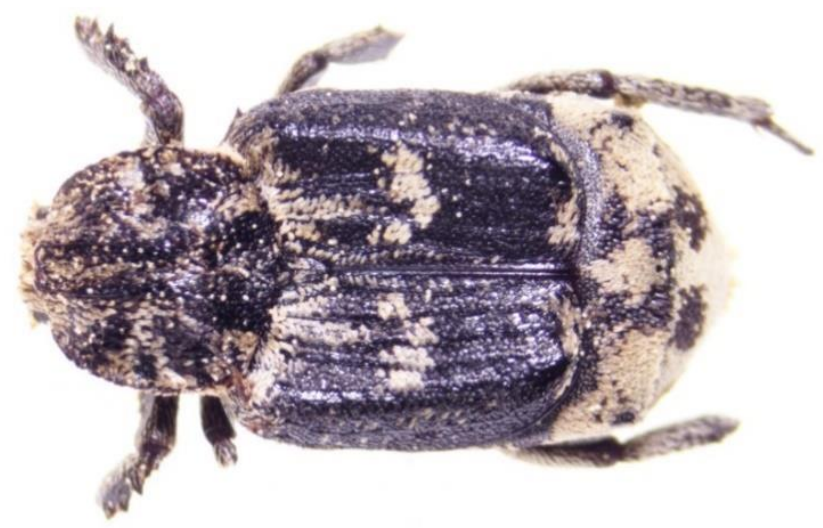

Şekil 3.1. Tropinota (Epicometis) hirta ergini 
Çalışmamızda Edirne Kent ormanında, $T$. hirta erginlerine süs bitkilerinde ve Ips sexdentatus için tesis edilen feromon tuzaklarında rastlanmıştır.

\subsubsection{Morimus ganglbaueri Reitter, 1894}

Morimus ganglbaueri'nin yayılışı ülkemizde İstanbul ve Denizli'de tespit edilmiştir. Meşe ağaçlarının gövdelerinde zararlı yaptıkları bildirilmektedir (Toper Kaygın, 2007). Erginleri koyu gri renkte olup, 20$25 \mathrm{~mm}$ boya sahiptir. Antenleri genellikle koyu renkte olup fazla kalın olan birinci parçası, üçüncü parçasından daha kısa boydadır (Şekil 3.2).

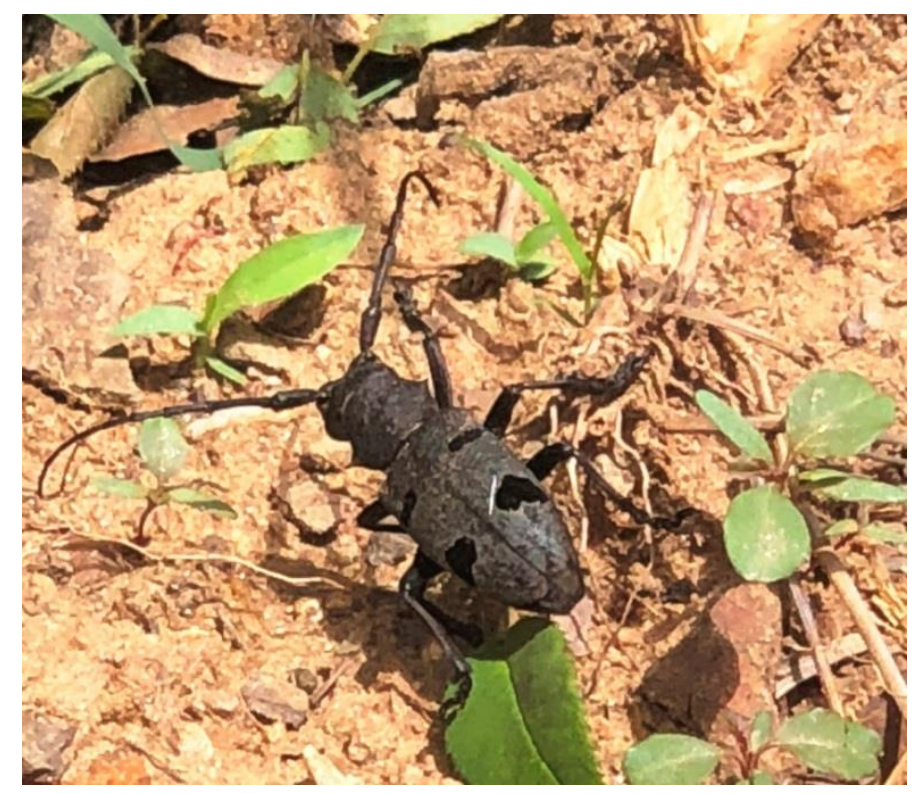

Şekil 3.2. Morimus ganglbaueri Reitter, 1894 ergini

Çalışmamızda, 19.06.2018 tarihinde kent ormanında bulunan yaşlı meşe ağaçlarının toprağa yakın kısımlarında rastlanmıştır.

\subsubsection{Scobicia chevrieri (Villa\&Villa, 1835)}

Scobicia chevrieri (Şekil 3.3), ülkemizde Kahramanmaraş Andırın Fagus orientalis sahalarında ve Aydın yöresinde Ficus carica üzerinde tespit edilmiştir (Akşit vd., 2005; Sarıkaya, 2017).

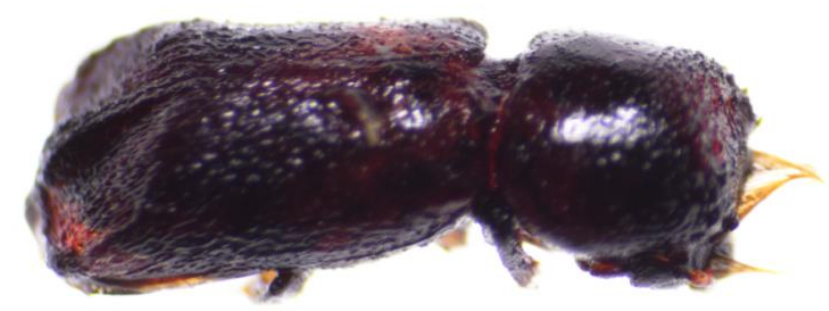

Şekil 3.3. Scobicia chevrieri (Villa\&Villa, 1835) ergini

Çalışmamızda Kent Ormanına tesis edilen kırmızı kanatlı yapışkan tuzaklarda 13.06.2018 ve 28.06.2018 tarihlerinde yapılan kontrollerde erginleri elde edilmiştir. 


\subsubsection{Hylurgus ligniperda (Fabricius, 1787)}

Hylurgus ligniperda Türkiye'de bazı bölgelerde $P$. pinea, $P$. nigra ve $P$. brutia'larda görülmüştür. Bu bölgeler Antalya, Isparta, Afyonkarahisar, Orhaneli-Çırpılık, Kozak Yukarıbeyler ve EskişehirÇatacık'dır (Schedl, 1961; Selmi, 1998, Sarıkaya, 2008). Erginlerinin vücudu uzunlamasına silindirik ve büyüklüğü 4,7-6 mm arasında olup, siyahımsı kahverenginde boyun kalkanı genişliğinden daha uzundur. Bacakları sarımtırak kahverengi, kanat örtüleri ise koyu kahverengindedir. Anten topuzu konik şeklinde ve kanat örtüleri üzerinde düzenli nokta şeritler vardır. Kanat örtüleri üzerindeki kıllar boyun kalkanındakilere göre daha kısadır (Şekil 3.4) (Sarıkaya, 2008).

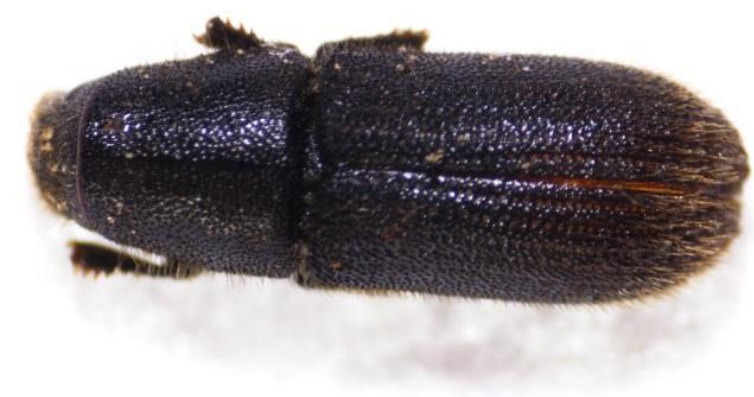

Şekil 3.4. Hylurgus ligniperda (Fabricius, 1787) ergini

Çalışmamızda Edirne Kent Ormanında kurumakta olan yaşlı bir karaçam ağacının gövdesinde 28.06.2017 ve 01.08.2018 tarihinde ise sahada Ips sexdentatus için asılı bulunan feromon tuzaklarında erginleri dikkati çekmiştir.

\subsubsection{Tomicus minor Hartig, 1834}

Tomicus minor'ün yayılış yaptığı alanlarda Pinus mugo, $P$. koraiensis, $P$. brutia, $P$. sylvestris, $P$. halepensis, $P$. nigra, $P$. densiflora, $P$. thunbergiana, $P$. rotundata ve $P$. strobus üzerinde bulunduğu bildirilmektedir. Ülkemizde Marmara, Akdeniz, İç Anadolu ve Karadeniz bölgelerinde Cedrus libani, Picea orientalis, $P$. brutia, $P$. sylvestris, $P$. nigra ve $P$. pinea türleri üzerinde tespit edilmiştir (Çanakçıoğlu ve Mol, 1998; Selmi, 1998, Sarıkaya, 2008). Yüksel vd. (2000) ise Sarıkamış P. sylvestris sahalarında böceğin varlığını bildirmiştir. Kanat örtüleri koyu kahverenginde olup sağrısı üzerinde 2 . nokta şeritlerinin arasında granül bulunmaktadır. Boyun kalkanı genişliğinden uzundur ve erginleri 3,2-4,8 $\mathrm{mm}$ arasındadır. Anten topuzu ile anten sapı arasında 6 segment vardır ve anten topuzu oval şeklindedir (Şekil 3.5).

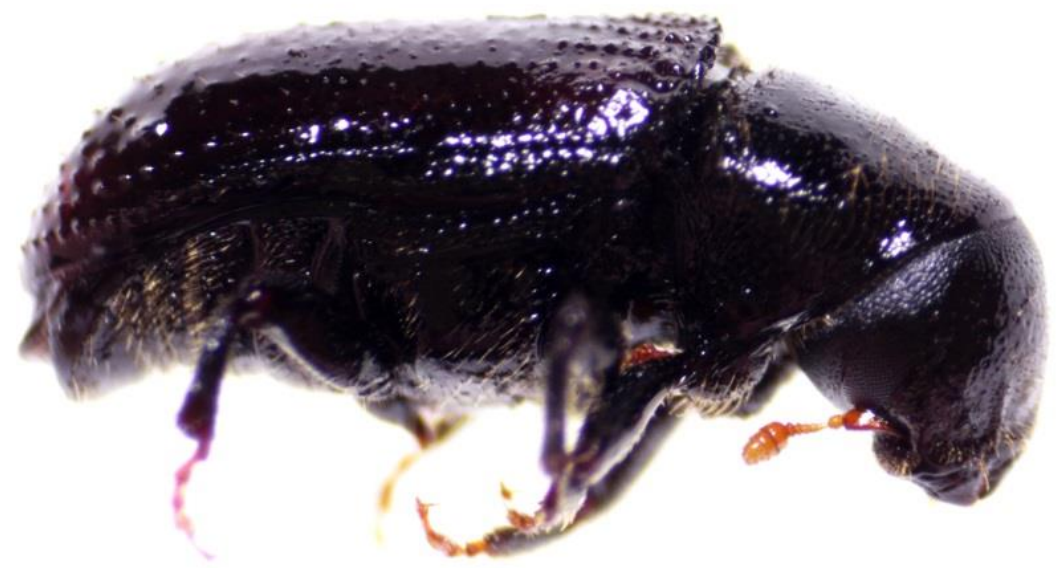

Şekil 3.5. Tomicus minor Hartig, 1834 ergini 
Çalışmamızda, kent ormanında kurumakta olan karaçam ağacının gövdesinde 13.04.2018 ve 22.04.2018 tarihlerinde yaptığımız kontrollerde martı kanadı şeklinde anayol açmakta olan erginleri dikkati çekerken; 01.07.2018 tarihinde kent ormanında yayılış gösteren karaçam bireylerinin kurumakta olan sürgünlerinde yaptığımız kontrollerde de olgunluk yiyimi yapmakta olan erginleri görülmüştür (Şekil 3.6).

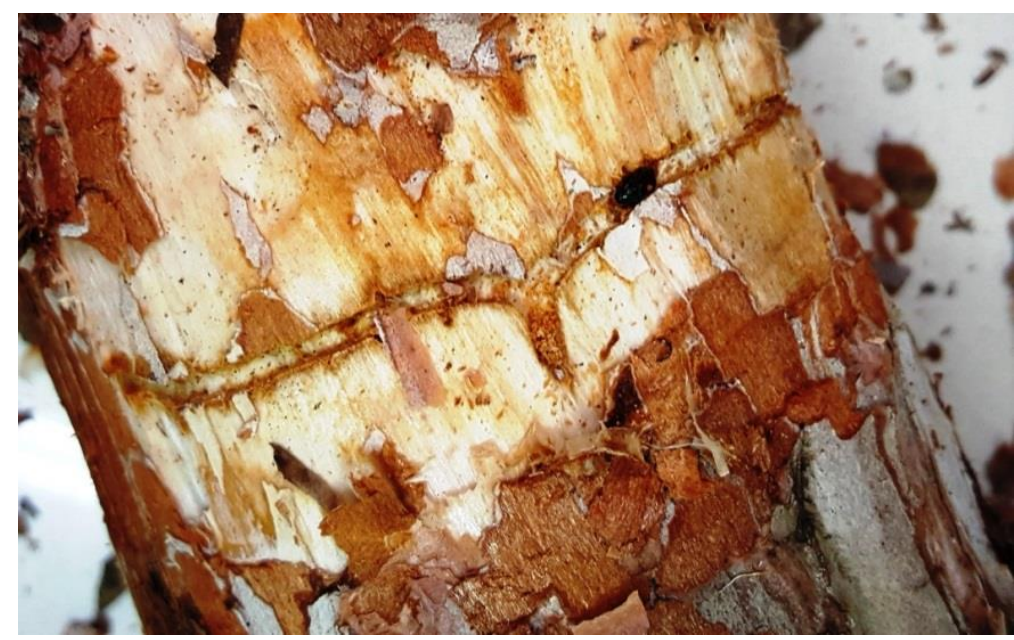

Şekil 3.6. Tomicus minor anayolu

\subsubsection{Taphrorychus ramicola (Reitter, 1894)}

Taphrorychus ramicola'nın ülkemizde Isparta, Bartın, Hatay ve Sakarya'da Fagus sylvatica ssp. Orientalis, Corylus avellana Quercus cerris ve Carpinus orientalis üzerinde tespit edilmiştir (Selmi, 1998; Selmi, 2011; Yıldız, 2012; Sarıkaya, 2013a, Sayın, 2014). Erginlerinin büyüklüğü 1,5-2 mm arasındadır. Kanat örtüleri nokta şeklinde ve uzunluğu genişliğinin yaklaşık iki katıdır. Kanat örtüleri buruşuk ve sağrısı noktalıdır. Erkek bireylerin alnında iplik şeklinde uzun ve sık kıllar bulunmaktadır (Şekil 3.7).

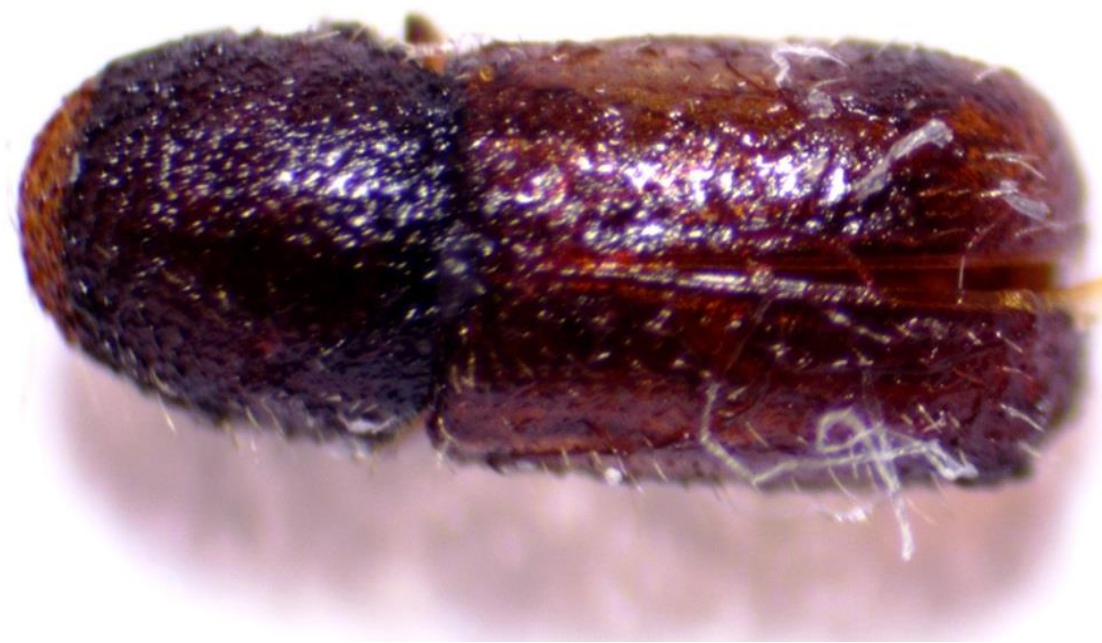

Şekil 3.7. Taphrorychus ramicola (Reitter, 1894) ergini

Çalışmamızda Kent Ormanına tesis edilen kırmızı kanatlı yapışkan tuzaklarda 18.05.2018, 13.06.2018 ve 28.06.2018 tarihlerinde yapılan kontrollerde erginleri elde edilmiştir.

\subsubsection{Taphrorychus villifrons (Dufour, 1843)}

Taphrorychus villifrons, ülkemizde Quercus cerris, Q. frainetto, Liquidambar orientalis, Carpinus betulus ve Fagus sylvatica subsp. orientalis türleri üzerinde Isparta, Sakarya, Tokat, Ankara, Hatay, 
İstanbul, Amasya, Bolu, Sinop ve Bursa'da yayılış göstermektedir (Schedl, 1961; Selmi, 2011; Yıldız, 2012; Sarıkaya 2013a; Sarıkaya, 2013b, Sayın, 2014). Erginlerinin büyüklüğü 1,9-2,4 mm arasındadır. Siyahımsı kahverengide olup bacakları ve antenleri açık kahverengindedir. 5-6 tüberkül bulunur kanat örtülerinin birleşme yerinde ve 3 . ve 5. nokta şeritlerinin arasında 3-5 adet ince tüberkül bulunmaktadır. Dişilerde kanat örtülerinin birleşme yerinde belirgin olmayan üç sıra granül ve birleşme yeri kanal şeklindedir. (Şekil 3.8).

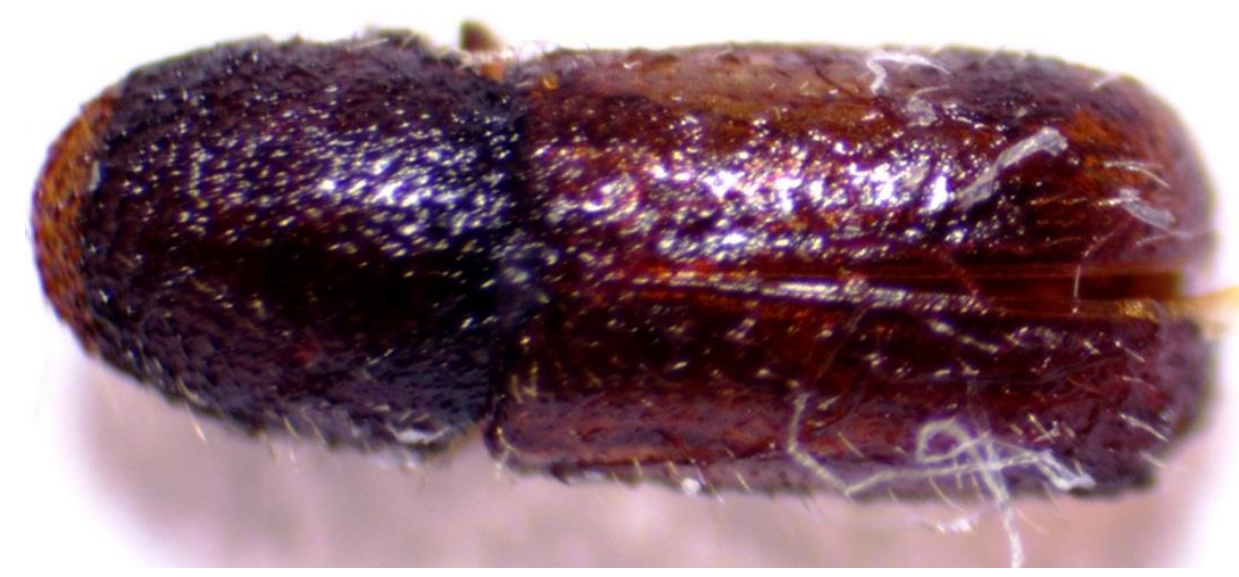

Şekil 3.8. Taphrorychus villifrons (Dufour, 1843) ergini

Edirne Kent Ormanında, Q. patraea ağaçlarına astığımız kırmızı kanatlı yapışkan tuzaklarda 23.05.2018, 09.06.2018 ve 16.07.2018 tarihlerinde yaptığımız kontrollerde erginleri elde edilmiştir.

\subsubsection{Ips sexdentatus (Boerner, 1766)}

Ips sexdentatus, ülkemizde Pinus sylvestris, P. nigra, P. brutia, Abies nordmanniana subsp. bornmülleriana, A. nordmanniana ve Picea orientalis türlerinde Doğu Anadolu, Karadeniz, Akdeniz, Ege ve iç Anadolu sahalarında yayılış yaptığı bildirilmektedir (Defne, 1954; Chararas, 1966; Tosun, 1975; Serez, 1984; Yüksel, 1998; Sekendiz, 1991; Yüksel vd., 2000; Yüksel vd., 2005, Sarıkaya ve Avcı, 2011). Erginlerin büyüklüğü 4,9-7,6 mm arasındadır. Kahverenginde kanat örtüleri bulunmaktadır. Vücudunun şekli silindirik biçimdedir. Boyun kalkanı daha koyu renkli ve boyu genişliğinden uzundur. 6'şar diş bulunur kanat örtülerinin sağrısının yan tarafında, 1. dişin uç kısmı kalınlaşmıştır. 3. diş ile 4. diş birlikte bulunmaktadır. 4. diş en uzun diştir ve uç kısmı kalınlaşmıştır (Şekil 3.9).

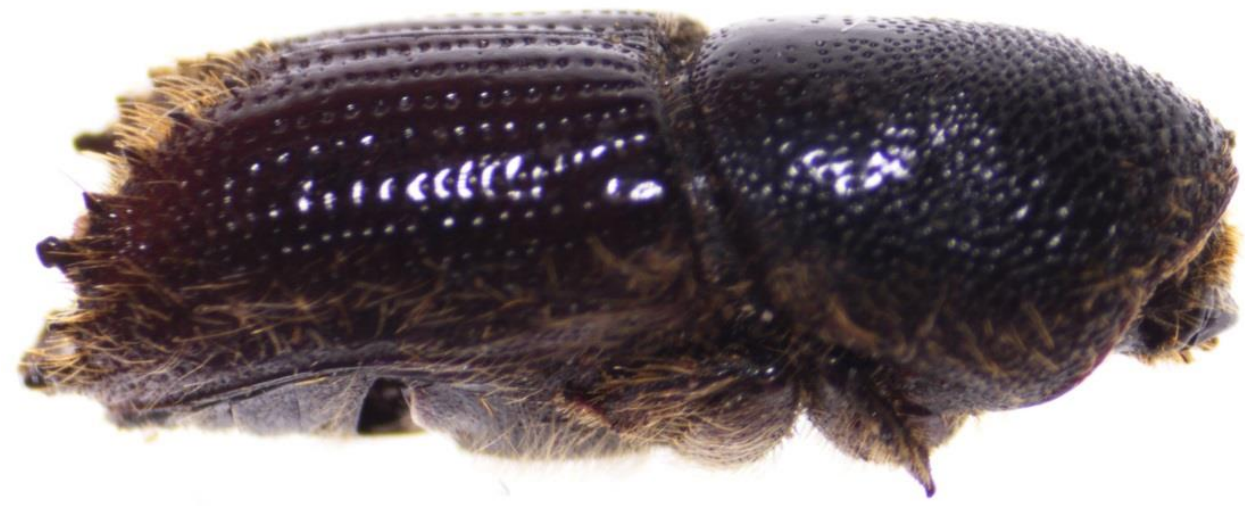

Şekil 3.9. Ips sexdentatus Boerner, 1766 ergini

Arazi çalışmalarımızda, Kent ormanında karaçam sahasına tesis edilen feromon tuzaklarıyla NisanEkim aylarını içerisine alan periyotta yoğun miktarda ergini elde edilmiştir. Ayrıca, 26.05.2018 tarihinde sahada kurumuş olan karaçam bireyinde yaptığımız gözlemlerde anayol açmakta olan erginleri tespit edilmiştir. 


\subsubsection{Orthotomicus erosus (Wollaston, 1857)}

Orthotomicus erosus, Türkiye'de Akdeniz, Ege, Marmara, İç Anadolu ve Karadeniz bölgelerinde yayılışı tespit edilmiştir (Selmi, 1998; Sarıkaya, 2008). Erginleri 2,5-3,7 mm büyüklüğündedir. Vücudu koyu kahverenginde, boyun kalkanı siyahımtırak kahverenginde ve kanat örtüleri kırmızımtırak kahverengindedir. Sağrısı vücut eksenine dik bir meyille aşağıya doğru inmektedir. Her iki tarafa döner diş bulunmaktadır sağrısında, bu dişler en çok erkek böcekte belirgindir. Birinci dişler konik ve sivri olup sağrının üst başlangıç noktası üzerinde bulunur. İkinci dişler üçgenimsi ve uç kısmı sivri şeklinde olup diğer dişlerden büyüktür. Bu dişin devamında iki adet daha diş vardır ve alt alta bulunmaktadır. Üçüncü dişler ise konik şeklinde ve eşit mesafede bulunmaktadır. Anten topuzlarında yuvarlak ve hafifçe kavisli şekilde iki adet dikiş olduğu görülmektedir (Şekil 3.10).

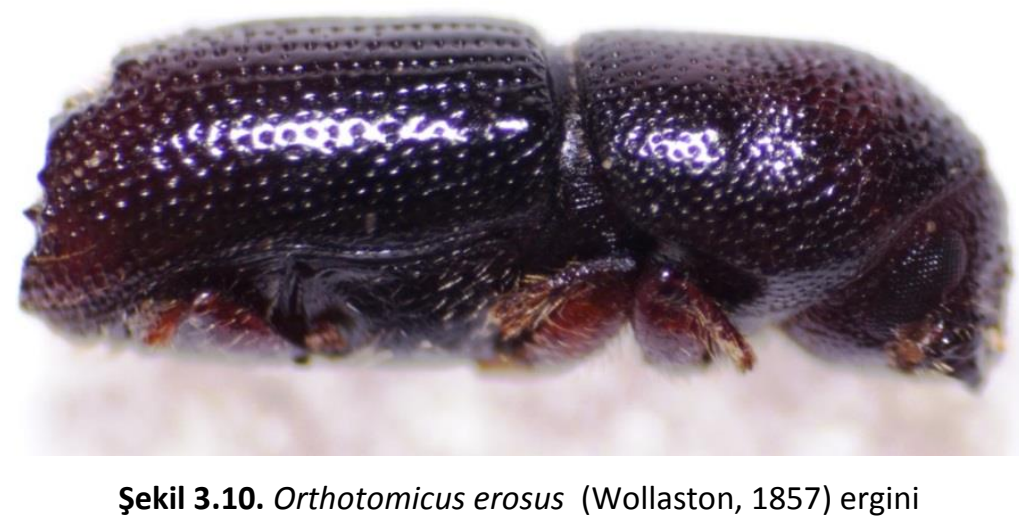

Kent ormanında karaçam sahasında, Ips sexdentatus zararından dolayı kurmakta olan karaçam ağaçlarında yaptığımız gözlemlerde 26.05.2018, 07.06.2018 ve 04.07.2018 tarihlerinde erginleri tespit edilmiştir.

\subsubsection{Scolytus mali (Bechstein, 1805)}

Scolytus mali, Türkiye'de İstanbul, Samsun, Ankara, Bolu, Amasya, Isparta'da Pyrus communis, Cydonia oblonga, Prunus armeniaca, P. domestica, P. persica, P. avium ve Malus domestica türlerinde bulunmuştur (Selmi, 2011; Sarıkaya ve Sayın, 2015, Sarıkaya vd., 2017). Erginleri 3-4,5 mm boyutunda ve genellikle kırmızımtırak veya kahverengindedir. Erkek erginlerin alınları kıllı ve düzdür (Şekil 3.11).

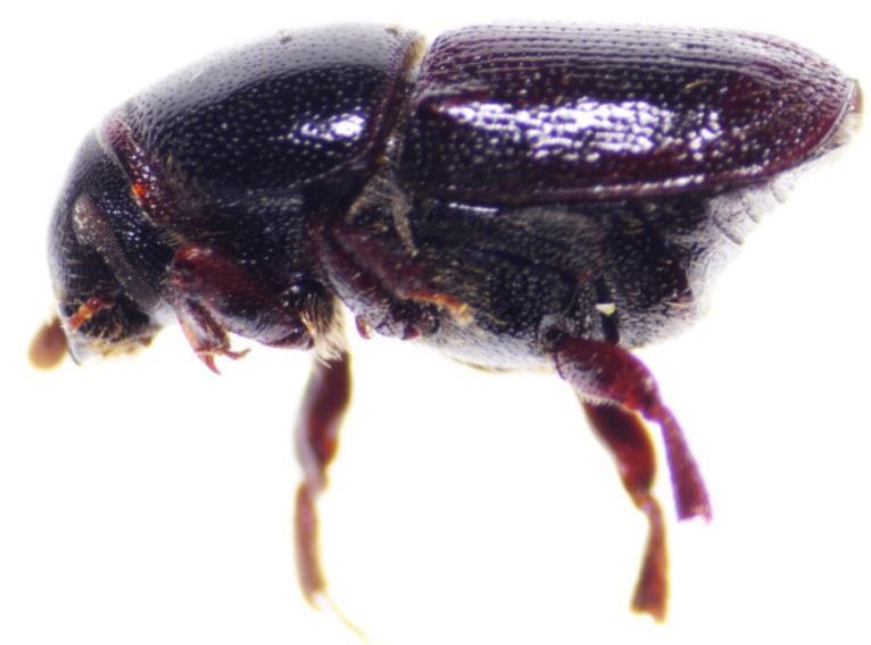

Şekil 3.11. Scolytus mali (Bechstein 1805) ergini 
Kent ormanında S. mali erginlerine, yapraklı ağaç türlerine tesis edilen kırmızı kanatlı yapışkan tuzaklarda 08.06.2018; 17.06.2018; 08.07.2018 ve 02.08.2018 tarihlerinde yaptığımız kontrollerde rastlanmıştır.

\subsubsection{Scolytus rugulosus (Müller, 1818)}

Scolytus rugulosus, ülkemizde Malus domestica, Tilia tomentosa, Acer platanoides, A. undulatum, Prunus armeniaca, P. cerasus, P. avium, P. dulcis, P. domestica, P. spinosa, P. persica, Crataegus sp., Cydonia oblonga, Quercus cerris, Pyrus communis ve Sorbus aucuparia üzerinde ve Balıkesir, Ankara, Isparta, Kahramanmaraş, Trabzon, Denizli, Antalya, İstanbul, Amasya, Bursa, Muğla, Niğde, Mersin, Adana, Manisa, İzmir, Malatya ve Osmaniye'de görülmüştür (Selmi, 2011; Sarıkaya, 2013a). Erginleri 1,4-3,0 mm büyüklüğündedir. Siyahımsı kahverengine sahiptirler. Dişilerde kısa tüyler bulunmakta ve abdomende sarımsı renkte olup erkeklerde ise alın kubbeli yapıda ve kısa tüylere sahip olup pronotum parlaktır. Kent ormanında yaptı̆ıımız tespitlere göre; Prunus armeniaca ve $P$. domestica ağacına tesis edilen Kırmızı yapışkan tuzakta 10.08.2018 tarihinde erginleri tespit edilmiştir.

\subsubsection{Anisandrus dispar (Fabricius, 1792)}

Anisandrus dispar ülkemizde Adana, Zonguldak, Bursa, Çorum, Giresun, Gümüşhane, Hatay, Bartın, Isparta, İstanbul, Karabük, Muğla, Artvin, Niğde, Ordu, Kastamonu, Rize, Sakarya, Denizli, Samsun, Ankara, Trabzon ve Bolu yörelerinde Carpinus betulus, Actinidia chinensis, Corylus avellana, Malus domestica, Ulmus sp., Prunus cerasus, Castanea sativa, Quercus sp., Tilia sp. ve Populus nigra üzerinde tespit edilmiştir (Schimitschek, 1944; Alkan, 1946;1948;1964; Schedl, 1961; Yıldız, 2012; Kaya, 2004; Cebeci ve Ayberk, 2010; Saruhan ve Akyol, 2012; Sarıkaya, 2013a; 2013b; Sarıkaya ve Sayın, 2016; Sarıkaya vd., 2017). Anisandrus dispar'ın erginleri yuvarlak olup ve 2,0-3,2 mm büyüklüğündedir. Uzunluğu ise elytranın genişliği kadardır. Kanat örtüleri nokta şeritli ve parlaktır. Vücudunun rengi siyahımtırak ve koyu kahverengidir. Anten ve bacakları kırmızımsı sarı rengindedir (Şekil 3.12).

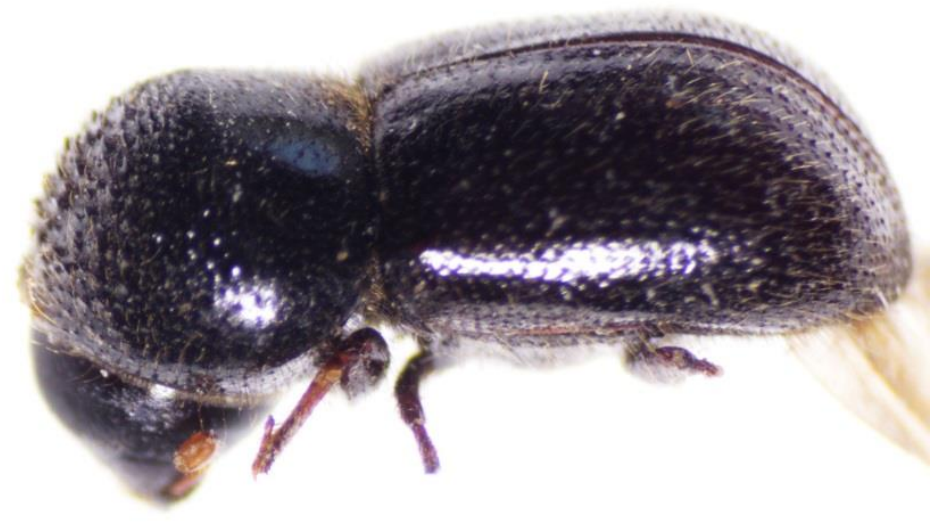

Şekil 3.12. Anisandrus dispar (Fabricius, 1792) ergini

Çalışmamızda, Kent Ormanında Söğütlük mevkide, yapraklı ağaç türlerine asılan kırmızı kanatlı yapışkan tuzaklarda; 19.06.2018, 11.07.2018, 30.07.2018, 10.08.2018, 19.09.2018 tarihlerinde yaptığımız kontrollerde erginlerine rastlanmıştır.

\subsubsection{Xyleborus monographus (Fabricius, 1792)}

Yayılış yaptığı yerlerde özellikle Quercus türlerinde zararı dikkati çekmektedir. Bunun yanı sıra, Acer, Fagus, Ulmus, Carpinus betulus, Juglans regia, Castanea sativa ve Prunus avium türlerinde bulunmuştur (Selmi, 1998). X. monographus (Şekil 3.13) ülkemizde, Afyonkarahisar, Bursa, Hatay, İstanbul, Kahramanmaraş, Castanea sativa, Fagus orientalis, Quercus frainetto ve Q. pubescens üzerinde tespit edilmiştir (Selmi, 1998; Sarıkaya ve Kavaklı, 2018). 


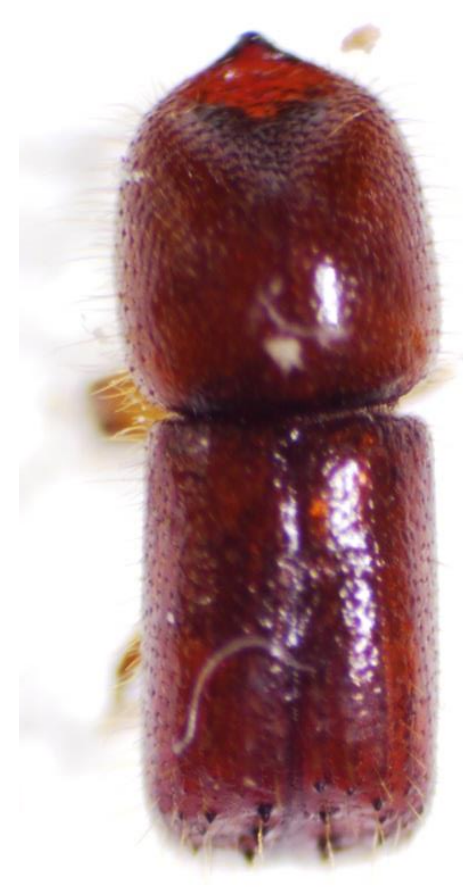

(a)

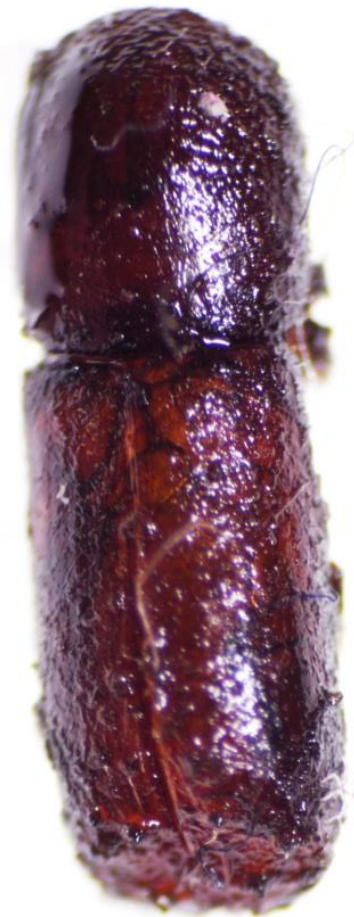

(b)

Şekil 3. 13. Xyleborus monographus (Fabricius, 1792) erginleri

(a) Erkek ergin (b) Dişi ergin

Çalışmamızda, Edirne Kent Ormanında, Q. petraea ağaçlarına astığımız kırmızı kanatlı yapışkan tuzaklarda 09.06.2018; 16.07.2018 ve 10.08.2018 tarihlerinde yaptığımız kontrollerde erginleri elde edilmiştir.

\subsubsection{Trypodendron lineatum (Olivier, 1795)}

Trypodendron lineatum, Avrupa, Kuzey Afrika, Sibirya, Japonya, Akdeniz çevresi ve Kuzey Amerika'da yayılış göstermektedir. Yayılış alanlarında, Picea abies, P. orientalis, Abies alba, A. bornmülleriana, A. nordmanniana, Pinus brutia, P. silvestris, P. montana, P. strobus, P. cembra, Cedrus libani, Larix decidua, L. sibirica ve Tsuga, Pseudotsuga, Thuja, Juniperus ile Sequoia'larda zarar yapmaktadır (Selmi 1998; Çanakçıoğlu ve Mol 1998; Yıldız, 2012). Renkleri kahveremgimsi siyah olup, boyun kalkanının kaidesiyle kanat örtüleri, anten ve bacakları sarımtrak kahverengi olup, boyun kalkanının eni boyuna oranla daha büyük ve dört köşelidir. Kanat örtülerinin her biri üzerinde uzunlamasına siyahımtrak renkte üç çizgi bulunmaktadır (Çanakçıŏlu ve Mol 1998; Yıldız, 2012) (Şekil 3.14).

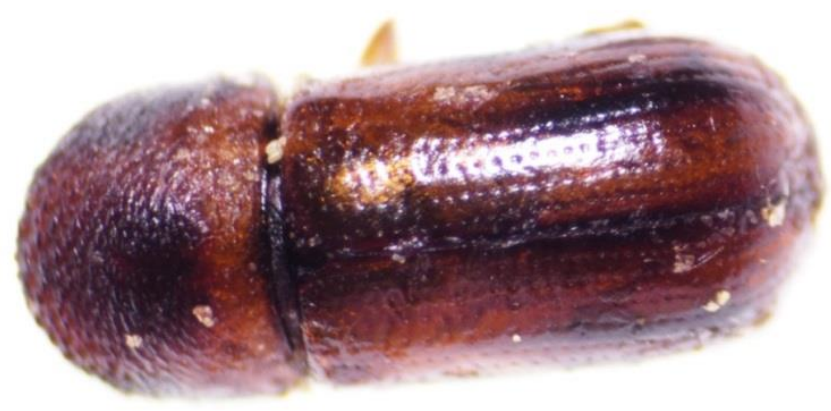

Şekil 3.14. Trypodendron lineatum (Olivier, 1795) ergini

Çalışmamızda, Edirne Kent Ormanında, astığımız kırmızı kanatlı yapışkan tuzaklarda 09.06.2018; 19.06.2018; 11.07 .2018 ve 10.08.2018 tarihlerinde yaptığımız kontrollerde erginleri elde edilmiştir. 


\subsubsection{Trypodendron signatum (Fabricius, 1787)}

Ülkemizde Fagus sylvatica ssp. Orientalis, Alnus sp. ve Quercus sp. türlerinde, Gümüşhane, Sakarya, Trabzon, Sinop, Karabük, İstanbul ve Bolu'da bulunmuştur (Selmi, 2011). Fraxinus excelsior, F. ornus, Acer platanoides, A. pseudoplatanus, Q. robur, Betula pendula, B. pubescens ve Quercus petraea üzerinde yayılış yapmaktadır (Pfeffer, 1995; Knižek, 2011). Erginleri 3,5-4 mm boyutundadır. Kanat örtüleri üzerinde hafif belirgin nokta şeritler bulunmakta olup koyu kırmızımtırak rengindedir. Boyu genişliğinin yaklaşık iki katı büyüklüğündedir (Şekil 3.15).

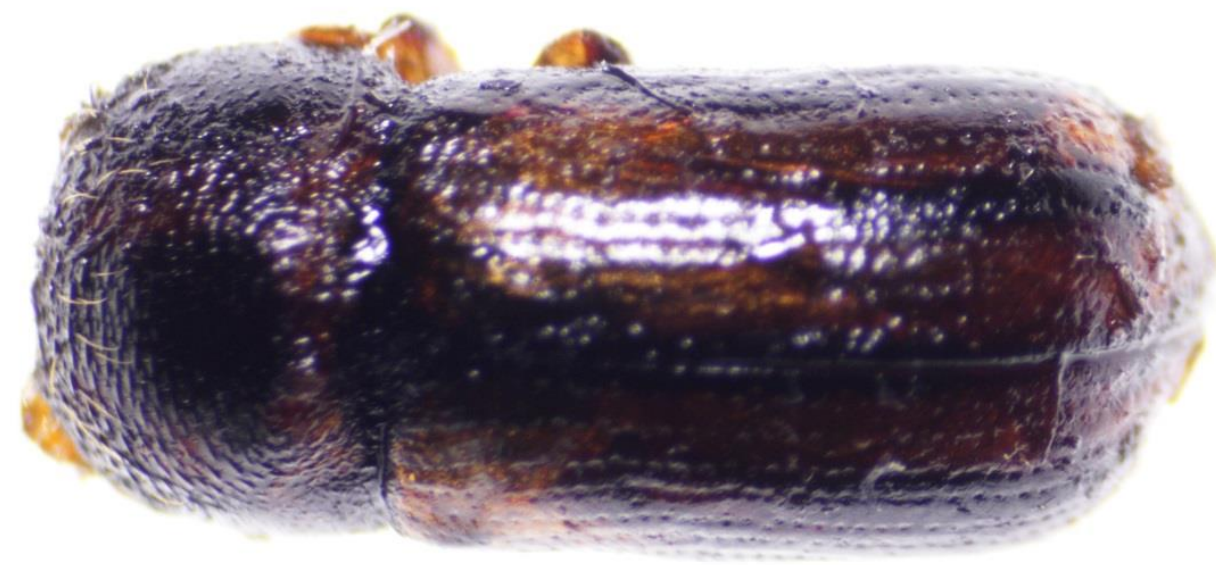

Şekil 3.15. Trypodendron signatum (Fabricius 1787) ergini

Çalışmamızda, Söğütlük mevkide kırmıı kanatlı yapışkan tuzaklarda 19.06.2018 tarihinde erginleri tespit edilmiştir.

\subsubsection{Xyleborinus saxesenii ( Ratzeburg, 1837)}

Xyleborinus saxesenii, ülkemizde Artvin, Samsun, Giresun, Hatay, İstanbul, Kocaeli, Düzce, Konya, Antalya, Mersin, Zonguldak, Muğla, Ordu, Rize, Sakarya, Bolu, Sinop, Trabzon, Amasya, bölgelerinde Cedrus libani, Actinidia chinensis, Quercus cerris, Corylus avellana, Juniperus excelsa, Fagus sylvatica subsp. orientalis, Ficus carica, Pyrus communis, Fraxinus ornus, A. nordmanniana subsp. bornmuelleriana, Juglans regia, Liquidambar orientalis, Pinus nigra, Alnus sp., Prunus armeniaca, $P$. avium ve Abies cilicica üzerinde bulunmuştur (Schedl, 1961; Chararas, 1965; Cebeci ve Ayberk, 2010; Yıldız, 2012; Saruhan ve Akyol, 2012; Sarıkaya, 2013a, Sarıkaya, 2013b; Sarıkaya ve Sayın, 2016; Sarıkaya vd., 2017).

Xyleborinus saxesenii erginleri 1,8-2 mm boyutundadır. Kanat örtüleriyle sağrısı ince noktalı olup boyun kalkanı genişliğinden daha uzun ve kubbemsi şeklindedir. Boyun kalkanının arka kısmı düz olup uzunluğu genişliğinden daha fazladır. Bacakları ile antenleri sarıdır. Boyun kalkanı ve başı açık renktedir (Şekil 3.16).

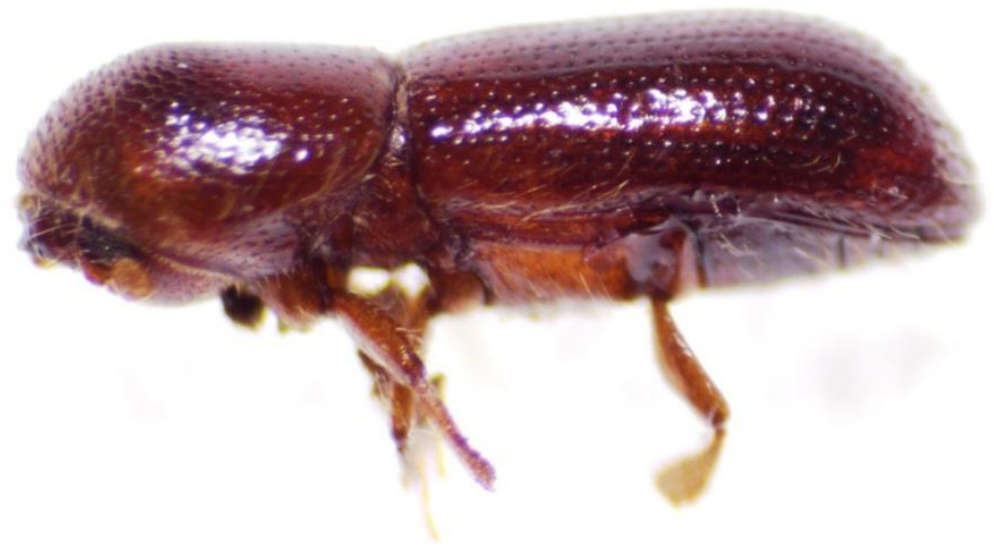

Şekil 3.16. Xyleborinus saxesenii ( Ratzeburg, 1837) ergini 
2018 yılında 07 Nisan tarihinde tesis edilen kırmızı kanatlı yapışkan tuzaklarda ilk $X$. saxesenii erginlerinin 09 Mayıs tarihinde gelmeye başladığı görülmektedir.

Hava sıcaklığındaki artışa bağlı olarak tuzaklardaki ergin sayıları giderek artmaya başlamış ve 10 Ağustos tarihindeki kontrollerde, ortalama hava sıcaklığının $22{ }^{\circ} \mathrm{C}$ üzerinde seyrettiği periyotta popülasyon en üst seviyeye ulaşmıştır. Bu tarihten sonra tuzaklara düşen ergin sayısında giderek azalma görülmekte olup, aktif uçma periyodunun Eylül ayı sonlarına kadar devam ettiği tespit edilmiştir.

\subsubsection{Lymantria dispar (Linnaeus, 1758)}

Lymantria dispar, ülkemizin hemen hemen tüm bölgelerinde yayılışı olan bu tür, meşeler başta olmak üzere yapraklı ormana ağacı türlerinde ve meyve ağaçlarında önemli zararları bulunmaktadır. Erginlerinin kanat açıklığı erkeklerde $35-40 \mathrm{~mm}$, dişilerde ise $55-70 \mathrm{~mm}$ kadardır. Erkekler grimsi kahverengi ile kırmızımtırak kahverengi arasında değişmektedir. Ön kanatları üzerinde koyu renkli enine zikzak çizgiler mevcuttur. Dişi erginlerde ise kanatlar daha kaba yapılı ve kirli beyaz renktedir. Ön kanatlarda koyu renkte enine uzanan zikzak ve dişli çizgiler mevcuttur (Şekil 3.17) (Çanakçıŏlu, 1998).

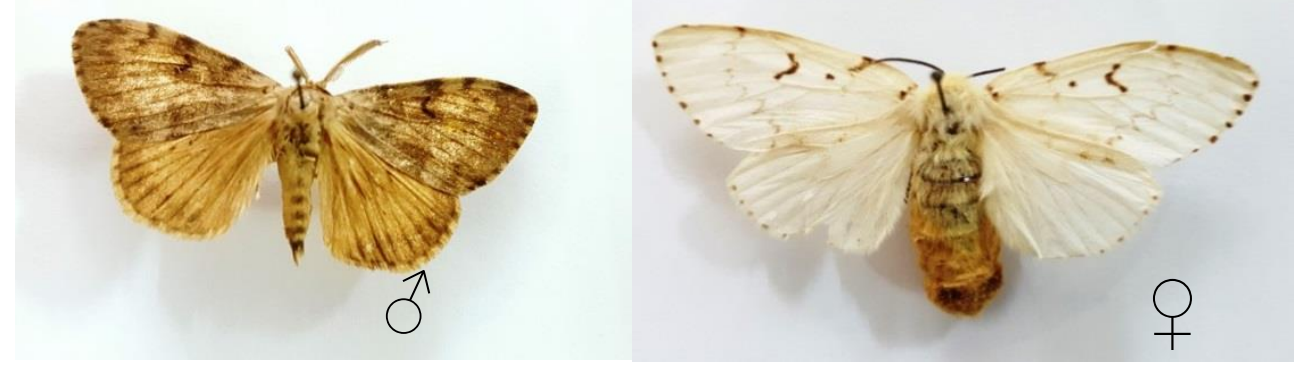

Şekil 3.17. Lymantria dispar (Linnaeus, 1758) erginleri

L. dispar ekonomik olarak önemli ölçüde zararlara sebep olan bir kelebek türüdür. Avrupa ve Asya'da zarar verdiği bilinen en az 100 tür bitki saptanmıştır. Meyve ağaçları ve özellikle ülkemizde meşe ağacı en çok saldırdıkları ağaçlardır. L. dispar larvaları larva evrelerini Haziran-Temmuz aylarında bu bitkiler üzerinde geçirdikten sonra, yaprakların arasında, ağaç kabuklarının ya da dalların üzerinde pupa olurlar. Çalışmamızda, sahadaki meşe (Quercus spp.) türlerinde yapraklarda tırtıl zararı tespit edilmiş ve 09.06.2018 tarihinde asılan Delta tipi feromon tuzaklarına, Ağustos ayı başına kadar yapmış olduğumuz kontrollerde erginlerinin geldiği görülmüştür.

\subsubsection{Malocosoma neustria (Linnaeus, 1758)}

Ülkemizde ilk kez 1965 tarihinde Adapazarı civarında meşeler üzerinde, 1967 tarihinde Edirne civarında melez kavaklarda ve 1968 'de de izmit'te Populus $x$ euramericana 1-214 ve $P$. nigra fidanlarında tespit edildiği belirtilmektedir (Sekendiz, 1974). Değişik araştırıcılar tarafından ise konukçuları olarak meşe, gürgen (Carpinus spp), söğüt, kavak (Populus spp.) ve fındık (Corylus avellana L.) gibi orman ağaçları ile çeşitli meyve ağaçları verilmektedir (Kansu, 1955; Bodenheimer, 1958; Sekendiz, 1974; İren, 1977; Çanakçıŏlu ve Mol, 1998). (Şekil 3.18).

Çalışmamızda, 19.06.2018 tarihinde Kuşburnu (Rosa canina) üzerinde zarar yapmakta olan larvaları dikkati çekmiştir (Şekil 3.18). 


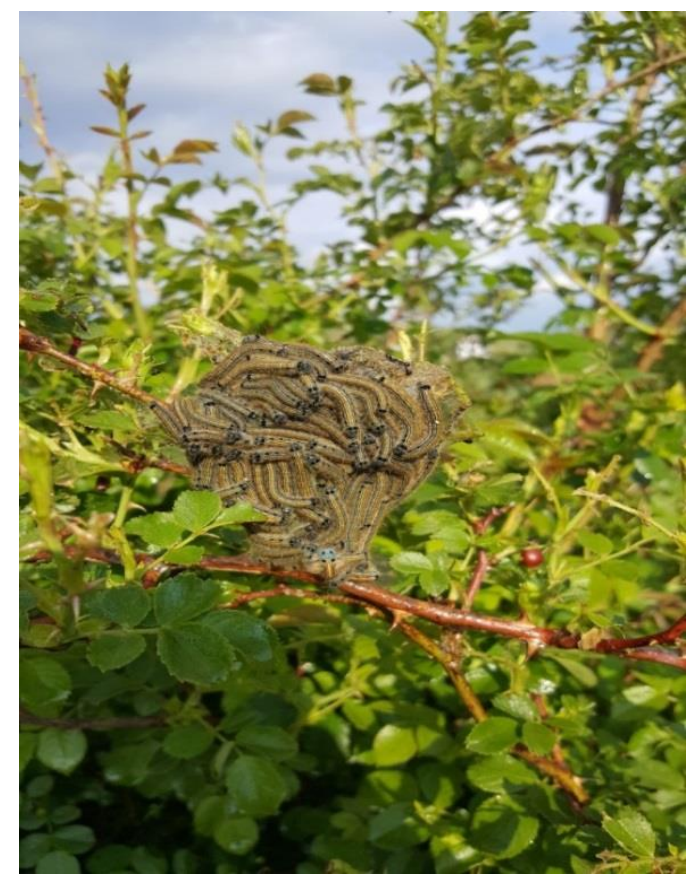

Şekil 3.18. Zarar yapmakta olan Malocosoma neustria larvaları

\subsubsection{Thaumetopoea wilkinsoni Tams, 1926}

Lepidoptera takımının Notodontidae familyasına aittir. Çam kese böceğinin erginlerinin ön kanat açıklığı dişide 35-40 mm, erkekte 30 mm'dir. Dişi erkeğe göre biraz daha büyüktür. Fakat erkek dişiye göre daha kuvvetli yapıdadır. Ön kanatlar dişide gri kül renginde erkekte ise gri rengindedir. Ön kanatların üzerinde zikzak çizgi mevcuttur. Arka kanatları beyaz renkli olup birer adet gri renginde leke mevcuttur. Antenleri çift taraklıdır (Şekil 3.19) (Çanakçığlu, 1998; Tosun, 1975).

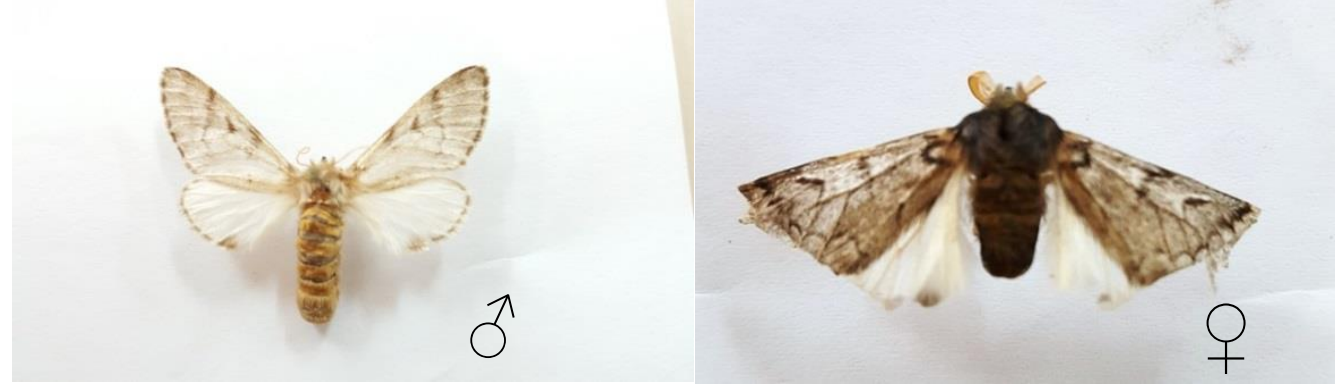

Şekil 3.19. Thaumetopoea wilkinsoni Tams, 1926 erginleri

Ülkemizde Cedrus libani, Pinus nigra, Pinus brutia, Pinus silvestris, Pinus halepensis ve Pinus pinea üzerinde tespit edilmiştir. Sedir ve çam türleri konukçuları arasındadır. Nisan sonunda veya mayıs başında toprağa giren larvalar bir koza örerler ve içerisinde pupa haline geçerler. Larvaların toprağa girme derinliği 2-30 cm arasındadır, toprağın fiziksel özelliklerine göre değişir. Larvaların toprağa girdiği yerler kabarık görünür, fakat fark zamanla kaybolur. Larvalar beş gömlek değiştirirler. Eğer uygun olmayan koşullar varsa pupalar toprakta 4 yıl boyunca diyapoz halinde kalabilirler. Ağustos sonu Eylül başlarında kelebekler topraktan çıkarlar kozalarını delerek ve erginlerin uçuş periyodu yöreden yöreye farklılık gösterir. Mesela Manavgat, Antalya ve Mersin'de Eylül ve Ekimde, Marmara Bölgesi'nde Temmuz ayında rastlanır (Çanakçıoğlu, 1998).

Çalışmamızda, sahada yer alan karaçam (Pinus nigra) ağaçlarında, keseleri dikkati çekmiş, ayrıca bu ağaçlara asılan Delta tipi feromon tuzaklarına Ağustos ayı başlarından itibaren başlayarak Eylül ayı ortasına kadar erginlerinin geldiği dikkati çekmiştir (Şekil 3.20). 


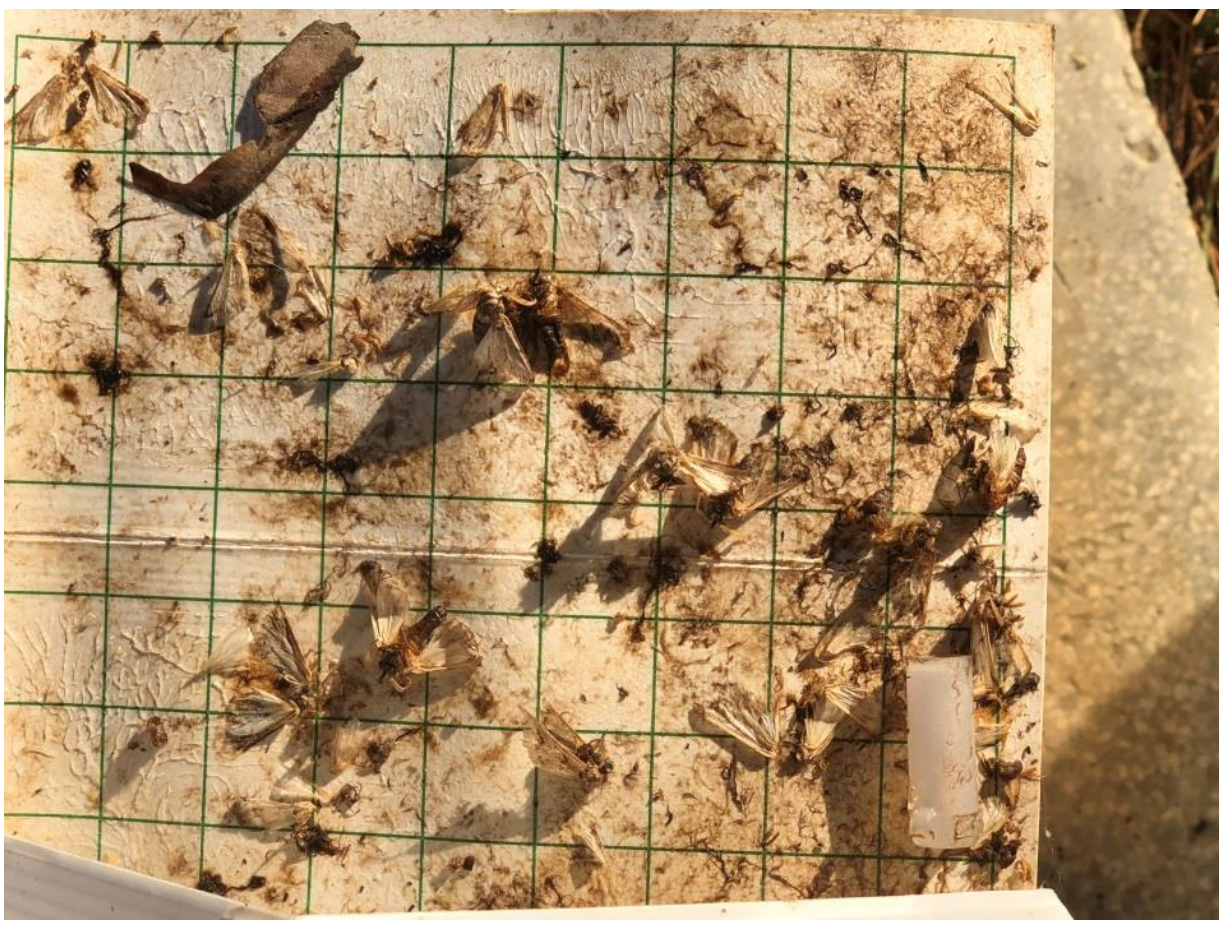

Şekil 3.20. Delta tipi feromon tuzağın yapışkan tablasına yapışan $T$. wilkinsoni erginleri

\subsubsection{Archips podana (Scopoli, 1763)}

Archips podana, Türkiye'de Marmara Bölgesi'nde İstanbul, İzmit, Çanakkale, Kırklareli ve Bursa'da Tilia argentea, Fraxinus angustilifolia, Populus spp., Quercus frainetto, Malus sp. ve Corylus colurna türlerinde tespit edilmiştir (Avcl, 1997). Erkek erginlerinde kanat açıklığı 21-23, dişilerde ise 25-27 mm kadardır. Erkeklerde ön kanatları açık kestane kahverengi, desenleri kırmızımsı kahverengi, median bandın iç kenarı yayılmış ve sub-terminal çizgi bant şeklindedir (Şekil 3.21). Dişilerde ise ön kanatların zemin rengi morumsu kahverengi, desenler daha belirgin ve koyu kahverengi olup, ağ şeklindeki radial damarlar kahverengidir.

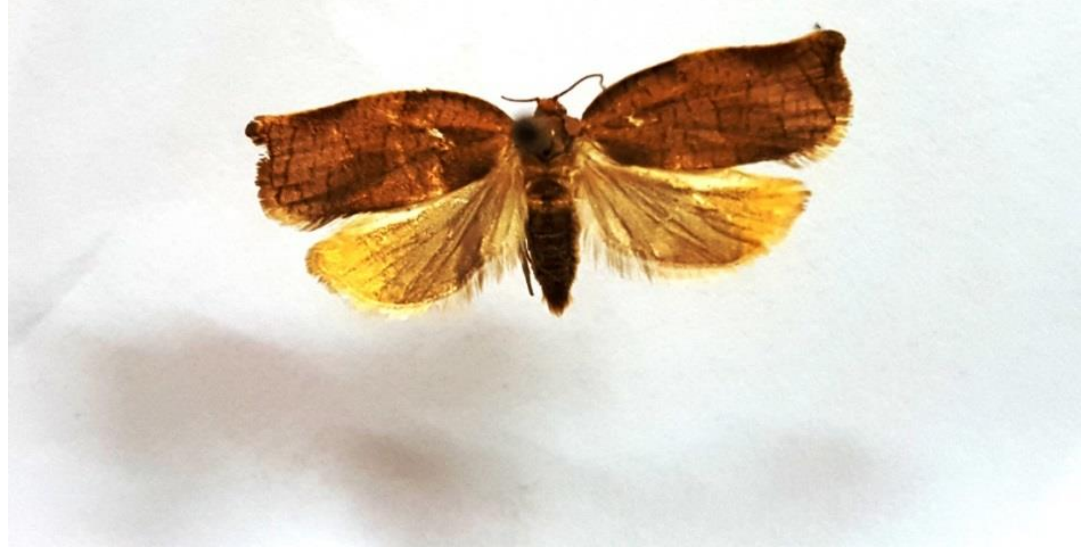

Şekil 3.21. Archips podana (Scopoli, 1763) ergini

Çalışmamızda, Edirne kent ormanında Quercus robur ağaçlarına asılan Delta tipi fromon tuzaklarında Haziran-Eylül ayları boyunca yaptığımız kontrollerde erginleri dikkati çekmiştir (Şekil 3.22). 


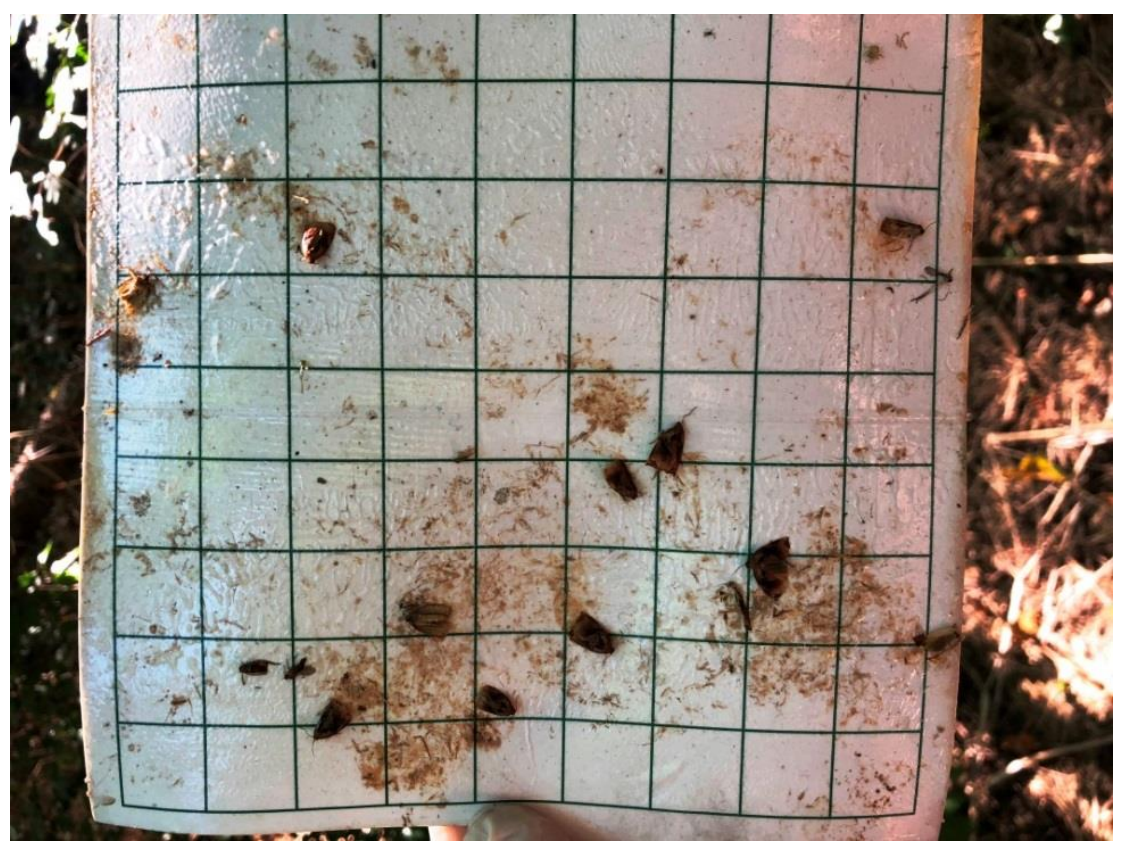

Şekil 3.22. Delta tipi feromon tuzağın yapışkan tablasına yapışan $A$. podana erginleri

\subsubsection{Archips rosana (Linnaeus, 1758)}

Archips rosana'nın ön kanatları yamuğumsu dikdörtgen şeklinde olup, renkleri açık zeytuni, zeytin yeşili ile kahverengi arasında değişiklik gösterir. Kanat açıklığı 18-22 mm genişliğindedir. Larvaları açık sarı-yeşil veya koyu yeşil ve baş kısmı kahverengi siyahtır (Şekil 3.23) (Ercan, 2013).

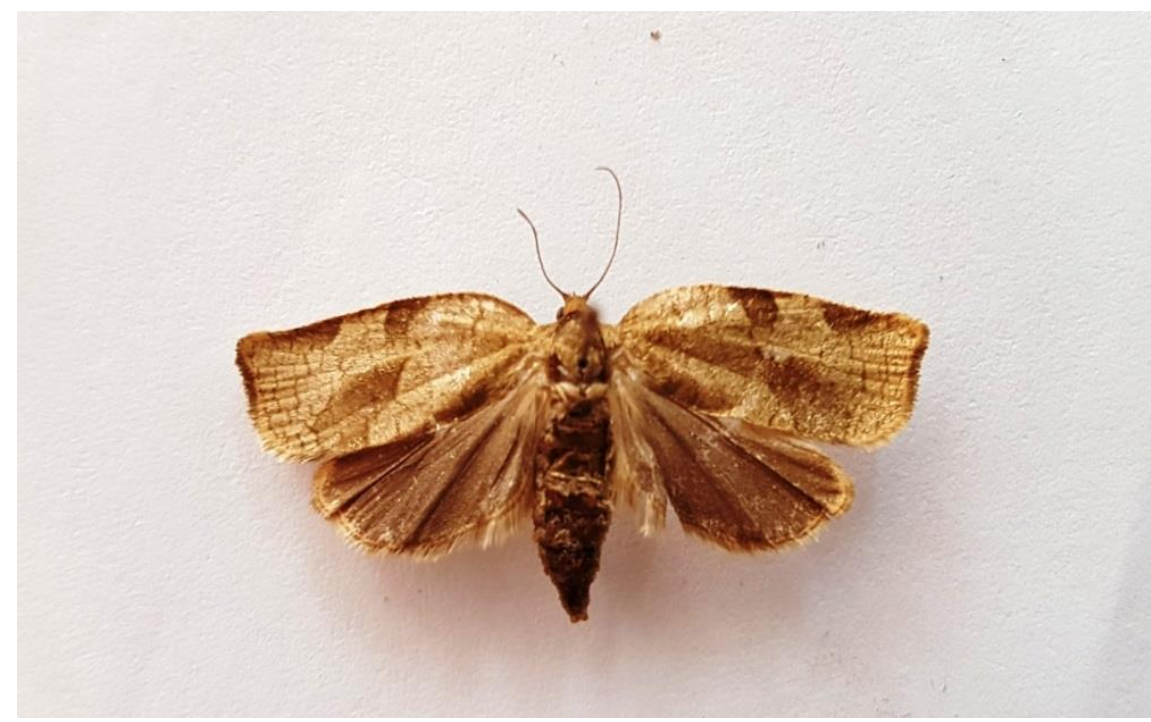

Şekil 3.23. Archips rosana (Linnaeus, 1758) ergini

Archips rosana, ülkemizde ise Marmara Bölgesinde Corylus, Prunus, Quercus, Alnus ve Ulmus'lar üzerinde tespit edilmiştir (Avcı, 1997). Çalışmamızda Kent ormanında Ulmus glabra ağaçlarına asılan Delta tipi feromon tuzaklarında, Haziran-Ağustos ayları arasında yapılan gözlemlerimizde erginleri dikkati çekmiştir.

\subsubsection{Tortrix viridana (Linnaeus, 1758)}

Tortrix viridana, ülkemizde bugüne kadar, İzmir, Ankara, Bartın, Marmara Bölgesi'nin geneli ve Afyonkarahisar'da yayılışı tespit edilmiştir (Çanakçıoğlu, 1998. Tuncer, 2014). T. viridana erginlerinin gerilmiş ön kanatlarının açıklığı 17-23 mm'dir. Dişi ve erkek (Şekil 3.24) bireylerde baş soluk sarı ile açık yeşil, gözler açık ile koyu kahverengi arasında değişmektedir. İplik şeklindeki antenleri 3,5-5,0 mm uzunluğunda açık kahverengi, flagellumu önce daha koyu renkli olup beyaz tüylerle örtülüdür. Bu 
tüyler erkeğin antenlerinde daha sıktır. Dişi kelebeğin abdomeni erkeğinkine oranla daha dolgun olup bunun son segmentinin uç kısmı kahverengidir (Çanakçıŏlu ve Mol, 1998; Tuncer, 2014)

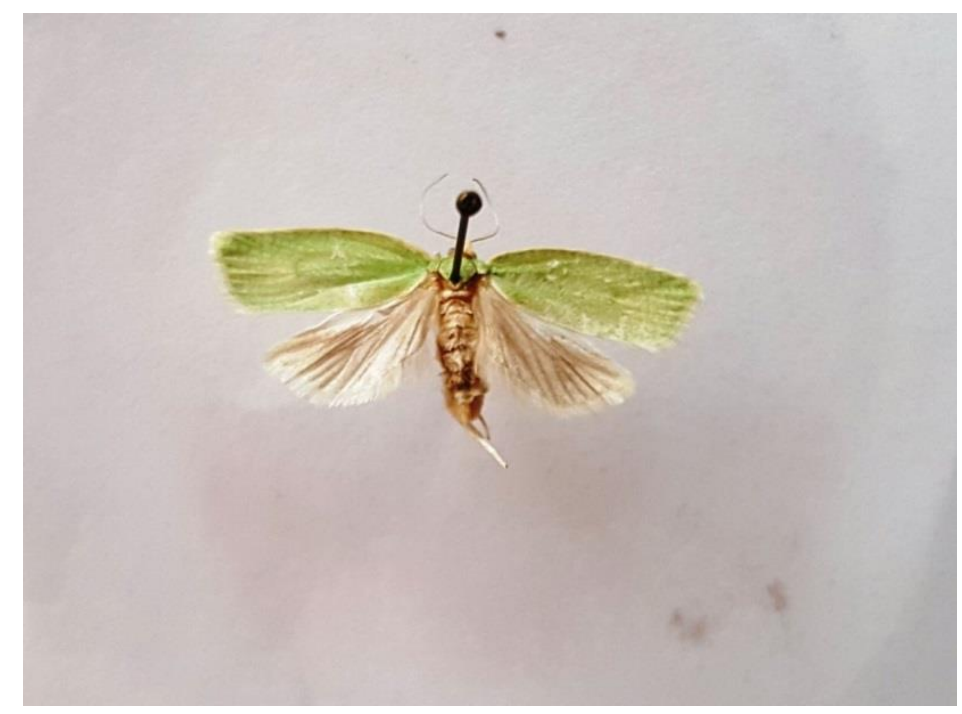

Şekil 3.24. Tortrix viridana Linnaeus, 1758 ergini

Edirne kent ormanında yürüttüğümüz çalışmalarda, Quercus ağaçlarına sılan Delta tipi feromon tuzaklarında Haziran ayının ikinci yarısından Temmuz ayı ortalarına kadar erginleri tespit edilmiştir.

\section{Sonuç}

Yeşil alanların azalmasına neden olan ve insan-çevre ilişkilerini zayıflatan faktörlerin başında hızı nüfus artışı, çarpık kentleşme ve sanayileşme gelmektedir. Bu nedenlerden dolayı günümüz insanının yeşil alan özlemi giderek bir artış göstermektedir (Erkmen, 2007). Bitkilerin, yeşil özellikleri ile kent formuna dinamik etki verme, gürültüyü maskeleme, rüzgâr, toz ve gaz etkilerini azaltma, hava kirliliğini önleme, iklim koşullarını iyileştirme ve estetik etkileri ile kent ve kırsal alana çok büyük katkıları vardır (Yılmaz, 1999; Erkmen, 2007).

Yapısallaşma plansız kentleşme ve kentin altyapı gibi sorunlarını da beraberinde getirmektedir. Kentte yaşayan insanların yorulan ruh ve bedenini iyileştirme isteği, nüfusun giderek artması ve yaşam standartlarının değişmesi kaynaklar üzerinde baskı oluşmakta doğal ve kültürel kaynaklara olan talebi artırarak yeni rekreasyonel etkinliklerin ortaya çıkmasına neden olmaktadır. Günümüzde de bu ihtiyacı karşılayan alanlardan biri kent ormanlarıdır. (Büyükyeğen, 2008).

Kent ormanı kentin yakınında veya içinde bulunan, insanların rekreasyonel ihtiyaçlarını karşılamasına yardımcı olan, kentin fauna ve florasını içinde barındıran alanlardır. Edirne yöresinin doğal ve kültürel özellikleri bize birçok olanak sunmaktadır. Aynı zamanda bize bu anlamda Edirne kent ormanı ekolojik yararlı kaynak oluşturmaktadır. Edirne kent ormanı konumu itibariyle yöre halkının nehir çevresinde yürüyüş, piknik, dinlenme, eğlenme, manzara seyri gibi doğal çevreden yararlanabildiği rekreasyonel amaçlı olarak çok sık ziyaret ettiği bir alandır.

Kent ormanlarımız üzerinde etkisi olan birçok biyotik ve abiyotik faktör vardır. Ormanların sağlığını etkileyen faktörler arasında böcekler önemli bir yer tutmaktadır. Yurdumuzda çok çeşitli bitki türlerinin bulunması, ormanlarda yıllarca varlığını hissettiren birçok böceğin yaşamasına imkân vermektedir. Bu durum bazı böceklerin sürekli, bazılarının da periyodik olarak zarar yapmalarına yol açmıştır (Sayın, 2014). Mesire yerlerinin sürdürülebilir kullanımını sağlamak için bu alanları tehdit eden böcek türlerinin belirlenmesi büyük önem taşımaktadır.

"Edirne Kent Ormanında Zararlı Biyotik Etmenlerin Belirlenmesi" başlıklı bu çalışma kapsamında Edirne Kent ormanında yayılış gösteren orman ağacı türlerinde Coleoptera ve Lepidoptera takımlarının 4'er familyasına bağlı zararlı toplam 22 adet böcek türü tespit edilmiştir. Bu türlerden; Morimus ganglbaueri Reitter, 1894 (Col.: Cerambycidae, Lamiinae), Scobicia chevrieri (Villa\&Villa, 1835) (Col.: Bostrichidae, Bostrichinae), Hylurgus ligniperda (Fabricius, 1787), Taphrorychus ramicola (Reitter, 1894), T. villifrons (Dufour, 1843), Scolytus mali (Bechstein 1805), S. rugulosus (Müller, 
1818), Anisandrus dispar (Fabricius, 1792), Xyleborus monographus (Fabricius, 1792), Trypodendron lineatum (Olivier, 1795), T. signatum (Fabricius 1787), Xyleborinus saxesenii ( Ratzeburg, 1837) (Col.: Curculionidae, Scolytinae); Malocosoma neustria (Linnaeus, 1758) (Lep.: Lasiocampidae, Malocosomatinae) ve Archips podana (Scopoli, 1763) (Lep.: Tortricidae, Tortricinae) Edirne yöresinde ilk kez tespit edilmiştir.

\section{Kaynaklar}

Akşit T. , Çakmak i.., Özsemerci, F. (2005). Some new xylophagous species on fig trees (Ficus carica cv. calymirna L.) in Aydın, Turkey. Turk. J. Zool., 29: 211-215.

Alkan, B. (1946). Kızılcahamam, Bolu (Abant) ve Düzce ormanlarında yapılan Entomolojik Araştırmalar. Orman ve Av. 3: 112-119.

Alkan, B. (1948). Fındık Ağaçlarının Zararlıları ve Korunma Çareleri. Ankara: Türk Yüksek Ziraat Mühendisler Birliği Yayınları. $16 \mathrm{p}$.

Alkan, B. (1964). Türkiye'nin bitki zararlısı kabuk böcekleri (Col., Scolytinae) faunası üzerine çalışmalar. Ankara Üniversitesi Ziraat Fakültesi Yıllığı. 14: 345-401.

Anonim, (2014a). Erişim Tarihi:05.10.2018. http://www.acilservis.pro/ekosistemde-canlilari-etkileyen-biyotikfaktorler

Anonim, (2014b). Erişim Tarihi:07.11.2018. http://www.edirnekentormani.com/Edirne-Kent-Ormani/

Arslangündoğdu, Z. (1999). İzmir Orman Bölge Müdürlüğünde böceklere karşı feromonların kullanılması üzerine araştırmalar. İstanbul Üniversitesi, Fen Bilimleri Enstitüsü, Yüksek Lisans Tezi, 69s, İstanbul.

Avcı, M. (1997). Marmara Bölgesi Ormanlarının Tortricidae (Lepidoptera) Faunası. İstanbul Üniversitesi, Fen Bilimleri Enstitüsü, Doktora Tezi, $127 \mathrm{~s}$.

Bodenheimer, F. S. (1958). Türkiye'de Ziraate ve Ağaçlara Zararlı Olan Böcekler ve Bunlarla Savaş Hakkında bir Etüt. (Çeviren: N. Kenter) Bayur Matbaası, Ankara, 320 s.

Büyükyeğen, G. (2008). Edirne Kent Merkezi ve Yakın Çevresi Rekreasyonel Kaynak Değerlerinin Sürdürülebilirlik Bağlamında Değerlendirilmesi. Zonguldak Karaelmas Üniversitesi, Fen Bilimleri Enstitüsü, Yüksek Lisans Tezi, 126s, Bartın.

Can, P. (2005). Türkiye Ormanlarında Son Yıllarda Görülen Kabuk böcekleri (Coleoptera, Scolytidae) Sorunu Üzerinde Bir Değerlendirme. Orman ve Av Dergisi, Sayı:2005-4, 4-11.

Çanakçığlu, H. (1985). Orman Koruma. İstanbul Üniversitesi Orman Fakültesi Yayınları, 486s., İstanbul.

Çanakçıŏlu, H., Mol, T. (1998). Orman Entomolojisi, Zararlı ve Yararlı Böcekler. İstanbul Üniversitesi Orman Fakültesi Yayınları, 541 s., ìstanbul.

Cebeci, H.H., Ayberk, H. (2010). Ambrosia beetles, hosts and distribution in Turkey with a study on the species of Istanbul province. Afr. J. Agri. Entomol. 5: 1055-1059.

Çetin, G., Hantaş, C., Erenoğlu, B. (2006). Bursa ve Yalova'da böğürtlen (Rubus fruticosus) bahçelerinde Saptanan zararlı böcek, akar faunası üzerine çalışmalar. Bahçe, 35(1-2), 61-74.

Chararas, C. (1965). Comportement de Xyleborus saxeseni Ratz., a l'égard de Liquidambar orientalis Mill., essence typique de l'Asie Mineure (Turquie). C.R. Acad. Sci. 260: 2313-2315.

Chararas, C. (1966). Picea orientalis'e Arız Olan Ips sexdentatus ve Diğer Kabuk Böcekleri. Ormancılık Araştırma Enstitüsü Dergisi, 12(1): 3-37.

Çoruh, S., Özbek, H. (2002). Erzurum Yöresinde Malacosoma neustria (L.) (Lepidoptera: Lasiocampidae)'nın Biyolojisi, Konukçuları ve Zararı Üzerine Bir Araştırma. Atatürk Üniversitesi Ziraat Fak. Dergisi, 33 (3), 283-287.

Çüçen, G. M. (2007). Erzurum Orman Fidanlığındaki Zararlı ve Faydalı Böcek Türleri. Kafkas Üniversitesi, Fen Bilimleri Enstitüsü, Yüksek Lisans Tezi, 75s, Artvin.

Defne, M. (1954). Ips sexdentatus Boerner Kabuk Böceğinin Çoruh Ormanlarındaki Durumu Ve Tevlit Ettiği Zararlar. i.ü. Orman Fakültesi Dergisi, 4(2): 80-91.

Demir, A. (2005). Gazi Üniversitesi Zooloji Müzesindeki Cetoniidae (Coleoptera) Familyası Örneklerinin Değerlendirilmesi. Yüksek Lisans Tezi, Gazi Üniversitesi, Fen Bil. Enst., Ankara, 124 s. 
Demirözer, O. (2008). Isparta ili yağ gülü (Rosa damascena Miller) üretim alanlarında bulunan zararlılar, yayılışları, doğal düşmanları ve önemlilerinin popülasyon değişimleri. Süleyman Demirel Üniversitesi, Fen Bilimleri Enstitüsü, Doktora Tezi, 152 s, Isparta.

Dwyer, J.F., McPherson, E.G., Schroeder, H.W., Rowntree, R.A. (1992). Assessıng The Benefits And Costs of the Urban Forest. Journal of Arboriculture, 18(5), 227-234.

Erkmen, N. (2007). Tasarım Bitkilerinin Arz ve Talebinin Belirlenmesi Üzerine Bir Araştırma: Edirne İli Örneğinde. Trakya Üniversitesi, Fen bilimleri Enstitüsü, Yüksek Lisans Tezi, 139s, Tekirdağ.

Fernández, M.M.F., Alonso, J.A.P., Costas, J.M.S. (1999a). Shoot feeding and overwintering in the lesser pine shoot beetle Tomicus minor (Col., Scolytidae) in north-west Spain. J. Appl. Ent. 123: 321-327.

Fernández, M.M.F., Alonso, J.A.P., Costas, J.M.S. (1999b). Oviposition and development of the immature stages of Tomicus minor (Coleoptera, Scolytidae). Agricultural and Forest Entomology 1: 97-102.

Hazır, A. (2008). Doğu Akdeniz Bölgesi şeftali ve nektarinlerde zararlı türler ille parazitoit ve predatörlerin saptanması, önemli zararlıların popülasyon gelişmesi ve mücadelede kullanılan bazı pestisitlerin Chilocorus bipustulatus L. (Coleoptera: Coccinellidae)'a etkisi. Çukurova Üniversitesi, Fen Bilimleri Enstitüsü, Doktora Tezi, 541s, Adana.

İren, Z. (1977). Önemli Meyve Zararlıları, Yayılışları ve Mücadele Metotları. Ankara Bölge Zirai Mücadele Araştırma Enst. Mesleki Eserler Serisi. No: 36.

Kansu, A. (1955). Orta Anadolu Meyve Ağaçlarında Zarar Veren Bazı Makrolepidoptera Türlerinin Evsafı ve Kısa Biyolojileri Hakkında Araştırmalar. İstiklal matbaası, Ankara.

Kaya, M. (2004). Bursa ilinde değişik meyve ağaçlarında Xyleborus dispar (F.) (Coleoptera: Scolytinae)'ın ergin popülasyon değişimi üzerine araştırmalar. Yüzüncü Yıl Üniversitesi, Ziraat Fakültesi, Tarım Bilimleri Dergisi. 14: 113-117.

Kaya, M., Kovancı, B. (2004). Bursa'da ahududu alanlarında saptanan Coleoptera türleri. Ondokuz Mayıs Üniversitesi Ziraat Fakültesi Dergisi, 19(3), 1-7.

Knížek, M. (2011). Scolytinae, In: Löbl, I. and Smetana, A. (eds.). Catalogue of Palaearctic Coleoptera, Vol. 7., Stenstrup: Apollo Books. p. 86-87, 204-251

Mendel, Z. (1983). Seasonal history of Orthotomicus erosus (Coleoptera:Scolytidae) in Israel. Phytoparasitica, 11: 13-24.

Mendel, Z., Ben-Yehuda, S., Marcus R., Nestor, D. (1997). Distribution and extent of damage by Scolytus spp. to stone and pome fruit orchards in Israel. Insect Science and its Application. 17: 175-181.

Mendel, Z., Halperin, J. (1982). The biology and behaviour of Orthotomicus erosus in Israel. Phytoparasitica, 10: 169-181.

Olgun, R. (2013). Kentsel yeşil alanlarda vandalizm ve olası tasarım çözümlerinin Antalya örneğinde incelenmesi. Akdeniz Üniversitesi, Fen Bilimleri Enstitüsü, Yüksek Lisans Tezi, 130s, Antalya.

Özkan, C., Gürkan, O., Hancıoğlu, Ö. (2005). Çubuk (Ankara) ilçesi vişne ağaçlarında zararlı olan türler, doğal düşmanları ve önemlileri üzerinde gözlemler. Tarım Bilimleri Dergisi, 11(1), 57-59.

Öztürk, N., Ulusoy, M.R., Erkılıç, L., Bayhan (Ölmez), S. (2004). Malatya ili kayısı bahçelerinde saptanan zararlılar ile avcı türler. Bitki Koruma Bülteni, 44(1- 4), 1-13.

Pfeffer, A. (1995). Zentral und westpaläarktische Borken und Kernkäfer. Naturhistorisches Museum Basel, 310 s.

Sağlam, S. (2012). İstanbul Metropolündeki Kent Ormanlarının Kullanım Kriterlerinin Belirlenmesi ve Planlama Esasları. İstanbul Üniversitesi, Fen Bilimleri Enstitüsü, Doktora Tezi, 124s, İstanbul.

Sarıkaya, (2008). Batı Akdeniz Bölgesi İğne Yapraklı Ormanlarının Scolytidae (Coleoptera) Faunası. Süleyman Demirel Üniversitesi, Fen Bilimleri Enstitüsü, Doktora Tezi, Isparta.

Sarıkaya, O. (2013a). Bark and Ambrosia Beetles Collected from Turkey Oak (Quercus cerris L.) Forests in Isparta Province of Turkey. Journal of Animal and Veterinary Advances, 12(11): 1038-1043.

Sarıkaya, O. (2013b). Notes on Bark and wood-boring beetles (Coleoptera: Bostrichidae; Curculionidae: Platypodinae and Scolytinae) of the Sweetgum (Liquidambar orientalis Mill.) Forest Nature Protection 
Area, with a new record for Turkish fauna. Journal of Food, Agriculture and Environment, 11(3\&4): 21782185.

Sarıkaya, O., Kavaklı, S.A., Sayın, H. (2017). Diversity of bark and wood boring beetles (Coleoptera: Bostrichidae; Curculionidae: Platypodinae and Scolytinae) on endemic and relict deciduous forest tree species in Mediterranean part of Turkey. International Scientific Conference Forest Science For Sustainable Development of Forests, 7-9 December 2017, Banja Luka, Bosnia and Herzegovina, p. 60-61.

Sarıkaya, O., Sayın, H. (2015). Observations on the flight activities of two ambrosia beetles Anisandrus dispar (Fabricius, 1792) and Xyleborinus saxesenii (Ratzeburg, 1837) in Kasnak Oak Forest Nature Protection Area in the South western of Turkey. International Journal of Agriculture Innovations and Research, 4(2): 357-360.

Saruhan, İ. ve Akyol, H. (2012). Monitoring population density and fluctuations of Anisandrus dispar and Xyleborinus saxesenii (Coleoptera: Scolytinae, Curculionidae) in hazelnut orchards. Afr. J. . Biotechnol. 11: 4202-4207.

Sayın, H., 2014. Kasnak Meşesi Tabiatı Koruma Alanı (Isparta-Eğirdir) Geniş Yapraklı Orman Ağaçlarında Kabuk Böceği Türlerinin Tespit Edilmesi Ve Önemli Türlerin Uçuş Dönemlerinin Belirlenmesi. Süleyman Demirel Üniversitesi, Fen Bilimleri Enstitüsü, Yüksek Lisans Tezi, 67s, Isparta.

Schedl, K.E. (1961). Borkenkäfer aus der Türkei, II. Mitteilung 190. Beitrag zur Morphologie and Systematik der Scolytoidea. 34: 184-188.

Schimitschek, E. (1944). Fortinsekten der Turkei und ihre Umwelt. Grundlagen der Türkischen Forstentomologie. Prag: Volk und Reich Verlag. xvi+371 p.

Sekendiz, O. A. (1974). Türkiye Hayvansal Kavak Zararlıları Üzerine Araştırmalar. Karadeniz Teknik Üniv. Yay. No: 62, Orman Fak. Yay. No: 3, $194 \mathrm{~s}$

Sekendiz, O.A. (1991). Abies nordmanniana (Stev.) Spach.'nın Doğu Karadeniz Bölümü Ormanlarındaki Zararlı Böcekleri Ille Koruma ve Savaş Yöntemleri. OGM Yayınları, Yayın No: 678, Sıra No: 73, 200 s.

Selmi, E. (1998). Türkiye Kabuk Böcekleri ve Savaşı. İstanbul: Emek Matbaacılık. 196 p.

Serez, M. (1984). Ips sexdentatus Savaşında Ips typographus'un Feromon Dispenseri “Ipslure” nin Kullanılması. Karadeniz Üniversitesi Orman Fakültesi Dergisi, 1: 35-43.

Sönmezyıldız, H. (2006). Bartın Yöresinde Fidanlarda ve Süs Bitkilerinde Zarar Yapan Böcekler. Zonguldak Karaelmas Üniversitesi, Fen Bilimleri Enstitüsü, Yüksek Lisans Tezi, 172s, Bartın.

Toper Kaygın, A. (2007). Endüstriyel Odun Zararlıları. Nobel Yayınevi.

Tosun, İ. (1975). Akdeniz Bölgesi, İğne Yapraklı Ormanlarda Zarar Yapan Böcekler ve Önemli Türlerin Parazit ve Yırtıcıları Üzerine Araştırmalar, İstanbul, 200s.

Tuncer, i. (2014). Dinar Yöresi Meşe Ormanlarında Yeşil Meşe Bükücüsü Tortrix viridana L. 1758 (Lep.; Tortricidae)’nın Zararı, Biyolojisi ve Doğal Düşmanları. Süleyman Demirel Üniversitesi, Fen Bilimleri Enstitüsü, Yüksek Lisans Tezi.

Uslu, Ş. ve Ayaşlıgil, T. (2007). Kent Ormanlarının Rekreasyonel Amaçlı Kullanımı Ve İstanbul ili Örneğinde İrdelenmesi, Yıldız Teknik Üniversitesi Mimarlık Fakültesi E-Dergisi 2(4), 213-236.

Wermelinger, B., Obrist, M.K., Duelli, P. and Forster, B. (1999). Development of the bark beetle (Scolytinae) fauna in windthrow areas in Switzerland. Mitt. Schweiz. Entomol. Ges. 72: 209-220.

Yıldırım, S. (2011). Isparta-Aksu Yöresi İğne Yapraklı Ormanlarında Zararlı Kabuk Böceği Türleri. Süleyman Demirel Üniversitesi, Fen Bilimleri Enstitüsü, Yüksek Lisans Tezi, 76s, Isparta.

Yıldız, Y. (2012). Bartın ve Karabük Ormanlarının Scolytinae Faunası Ve Bazı Önemli Türlerin Biyolojilerinin Belirlenmesi. Bartın Üniversitesi, (Basılmamış) Doktora Tezi. 139 p.

Yılmaz, R. (1999). Otoyol Peyzaj Planlamasında Kullanılmaya Uygun Bazı Doğal Otsu ve Odunsu Bitkilerin Otoyol ve Fidanlık Koşullarında Yetiştirilme Olanakları Üzerinde Araştırmalar. Ege Üniversitesi, Fen Bilimleri Enstitüsü, Doktora Tezi, 238s, İzmir.

Yüksel, B. (1998). Türkiye'de Doğu Ladini (Picea orientalis (L.) Link.) Ormanlarında Zarar Yapan Böcek Türleri ile Bunların Yırtıcı ve Parazitleri, Doğu Karadeniz Ormancılık Araştırma Enstitüsü, Teknik Bülten No: 4, VII+143 s. 
Yüksel, B., Tozlu, G., Şentürk, M. (2000). Sarıkamış Sarıçam (Pinus sylvestris L.) Ormanlarında Etkin Zarar Yapan Kabuk Böcekleri ve Bunlara Karşı Alınabilecek Önlemler. T.C. Orman Bakanlığı Doğu Akdeniz Ormancılık Araştırma Müdürlüğü, Teknik Bülten No: 3, Orman Bakanlığı Yayın No: 107, DAOA Yayın No:8, 66 s. 